NBER WORKING PAPER SERIES

\title{
LAND AND HOUSE PRICE MEASUREMENT IN CHINA
}

\author{
Yongheng Deng \\ Joseph Gyourko \\ Jing Wu \\ Working Paper 18403 \\ http://www.nber.org/papers/w18403 \\ NATIONAL BUREAU OF ECONOMIC RESEARCH \\ 1050 Massachusetts Avenue \\ Cambridge, MA 02138 \\ September 2012
}

This paper was prepared for the Reserve Bank of Australia and Bank for International Settlements conference on "Property Markets and Financial Stability" in August of 2012. We appreciate the comments of Haibin Zhu and other conference participants on an earlier draft, and gratefully acknowledge Jia $\mathrm{He}$ and Mingying Xu for excellent research assistance. Gyourko thanks the Global Research Initiatives Project of the Wharton School, University of Pennsylvania for financial support. Deng and Wu thank the Institute of Real Estate Studies at National University of Singapore for financial support. Wu also thanks the National Natural Science Foundation of China for financial support (No. 71003060). The views expressed herein are those of the authors and do not necessarily reflect the views of the National Bureau of Economic Research.

NBER working papers are circulated for discussion and comment purposes. They have not been peerreviewed or been subject to the review by the NBER Board of Directors that accompanies official NBER publications.

(C) 2012 by Yongheng Deng, Joseph Gyourko, and Jing Wu. All rights reserved. Short sections of text, not to exceed two paragraphs, may be quoted without explicit permission provided that full credit, including (C) notice, is given to the source. 
Land and House Price Measurement in China

Yongheng Deng, Joseph Gyourko, and Jing Wu

NBER Working Paper No. 18403

September 2012

JEL No. R0,R14,R3,R31

\begin{abstract}
$\underline{\text { ABSTRACT }}$
We provide the first multi-city, constant quality land price index for 35 major markets in China. While there is meaningful heterogeneity in land price growth across cities, on average the last nine years have seen land values skyrocket in many markets, not just those on or near the coast. The typical market has experienced double-digit compound average annual growth in real, constant-quality land values. The 2009-2010 stimulus period typically saw large surges in prices. Three notable characteristics about the land value appreciation series are their strong mean reversion at annual frequencies, the strong common factor in their movement, and their very high volatility. Quantities, not just prices, have been sharply increasing in recent years. The typical amount of space supplied via land auctions in our 35 city sample has doubled since 2008. Some local political economy traits such as the time the local Chinese Communist Party leader has been in office are correlated with land supply volume.

We also investigate the quality of the two most prominent house price indexes in China, and conclude that a traditional hedonic index more accurately reflects how house prices have changed over time in eight major markets in China. Repeat sales indexes have become standard in many countries, but they are not as useful in emerging markets such as China because the bulk of the housing stock is relatively new and has not traded multiple times. A hedonic index shows much higher house price growth over time that do officially published series for the eight markets examined.
\end{abstract}

Yongheng Deng

Institute of Real Estate Studies

National University of Singapore

Singapore

ydeng@nus.edu.sg

Joseph Gyourko

University of Pennsylvania

Wharton School of Business

3620 Locust Walk

1480 Steinberg-Dietrich Hall

Philadelphia, PA 19104-6302

and NBER

gyourko@wharton.upenn.edu

\author{
Jing $\mathrm{Wu}$ \\ Institute of Real Estate Studies \\ Tsinghua University \\ 100084 Beijing, P.R.China \\ ireswujing@tsinghua.edu.cn
}




\section{Introduction}

The stability of residential property markets has become an important topic for policy makers and scholars ever since the collapse of the subprime mortgage market in the United States helped precipitate the largest economic crisis seen in that country since the Great Depression. Many commentators now are raising questions about the stability of house prices in China given its extraordinary boom in values and its growing share of global growth. ${ }^{1}$

In this paper, we take a closer look at the Chinese housing markets, investigating two of their features in detail. One is the land market. China is virtually unique globally in that transactions prices of vacant land are regularly observed. We construct constant quality land price indexes for 35 major cities and analyze their characteristics.

The other aspect of the housing market studied here is how best to measure price appreciation. Without an accurate gauge of real, constant quality prices, neither investors nor policy makers can be well-informed about the true condition of the property markets. Ever since Case and Shiller (1987) popularized repeat sales price indexes in the United States, they have become the gold standard for house price measurement, replacing the older hedonic techniques that were used to adjust for quality drift in the housing stock. However, China, along with many emerging markets, provides a unique challenge to the use of repeat sales indexes because there is plentiful new construction but few cases of multiple sales of existing untis. Drawing on the work of Wu, Deng and Liu (2011), we show that the older hedonic modeling approach generates a more accurate picture of house price growth in Chinese markets.

\footnotetext{
${ }^{1}$ See the reports in Foreign Affairs ("China's Real Estate Bubble May Have Just Popped”, Dec 18 $8^{\text {th }}$, 2011), the New York Times ("Will China Break", Dec 18 $8^{\text {th }}$,2011) or the Financial Times ("Chinese property: a lofty ceiling", Dec $13^{\text {th }}, 2011$ ) for some recent examples.
} 
The first part of the paper reports results on land price appreciation and sales quantity growth based on a new and unique data set on residential land markets across 35 major Chinese cities. Key stylized facts about Chinese land markets include the following. Residential land values have skyrocketed in China over our 2003-2011 sample period. Even with the recent pullback in land prices in 2011 observed in many markets, the average annual compound rate of real, constant quality land price growth still is above $10 \%$ in the typical market and exceeds $20 \%$ per annum in eleven cities. Extremely high rates of price appreciation are not restricted to the big coastal region markets such as Beijing and Shanghai, which experienced real annual growth rates of $20.2 \%$ and $23.7 \%$, respectively. In fact, the city of Hefei, the capital of Anhui province in central China, has the highest real annual average growth rate of $30.1 \% .^{2}$ In addition, the markets of Changsha, Chongqing, Lanzhou, Nanjing, and Tianjin are almost indistinguishable from Beijing and Shanghai in the magnitudes of their land price growth. The first three of those cities are in the central or western region of the country. In addition, there is heterogeneity in the magnitude of price growth across markets, with eight (Jinan, Kunming, Nanchang, Shijiazhuang, Qingdao, Yinchuan, Xian, and Wulumuqi) seeing real land prices grow at less than $10 \%$ a year on average. Only one market, Wulumuqi, has negative price growth over its time in our sample, and we have data on that city for only five years.

While there are strong common year effects in land price appreciation, city fixed effects cannot explain virtually any of the variation. Thus, prices tend to move in the same way across most markets in a given year, possibly due to shifts in the Chinese

\footnotetext{
2 Technically, Xining has a higher annual rate of appreciation at $49.9 \%$, but we only have three years of data on that market.
} 
macro environment or national market sentiment. There also is large mean reversion in annual price growth, on the order of $35 \%$. This is quite different from what other researchers have found for U.S. housing (not land) markets over short horizons such as a year. A preliminary investigation suggests that frequent adjustment of central government policies is a factor in explaining this pattern. Mean reversion in land price growth is larger if land prices were increasing in the previous year. This is consistent with evidence that the Chinese government intervenes regularly to tame the property market.

Land prices also are quite volatile-3-5 times more so than house prices according to our data. Construction costs are fairly flat in our sample period and construction worker wages grow strongly but with relatively low variation about trend, so the volatility in house prices appears to be driven by the land market, not by other factors of production.

We also document the supply side of local land markets, showing a doubling of space supplied via land auctions just since 2008. City fixed effects are influential in explaining the variation in new supply, but there also is an economically meaningful common, national component present. In addition, we provide evidence that local political economy factors can help explain the variation in supply over time within a given market. Land sales volume is higher the more recently the local Chinese Communist Party chief took over. It also is higher if local government has been spending more than it takes in in budgetary revenues, forcing it to rely more on land sales as an important source of funds. 
The second part of our paper focuses on measurement of house price changes in China. Most of the housing stock is relatively new and has not transacted multiple times. Hence, it is impractical to construct house prices indexes using paired repeat sales transaction data. Presently, there are two widely-known price series reported in China. One reflects the simple average of transactions prices within each city on new housing units, with no attempt to control for heterogeneity in the quality of the housing units and markets. The other reflects the comparison of the average prices of new units sold in individual housing complexes during different stages of the complexes' sales periods. This series is an average of changes in complex-based average prices over different sale stages and over time.

The behavior of the simple average series varies widely across markets. It shows more starkly rising prices in bigger, more developed coastal markets than in smaller, less developed interior ones. The second series based on changes in average prices within a housing complex exhibits little price growth over time and little volatility in general. Relying on the analysis in Wu, Deng and Liu (2011), we show that both indexes suffer from severe biases. The simple average house price index underestimates true constant quality price growth due to falling quality over our sample period. ${ }^{3}$ The comparison of complex-level average pricing across sales stages over time also suffers from downward bias due to both unobserved unit-level heterogeneity and developers' strategic pricing behavior (i.e., Chinese residential housing developers typically sell the better units with higher prices earlier, and gradually drop prices in later stages.) We contrast these two series with a traditional hedonic-based index that we estimate separately, and argue that

\footnotetext{
${ }^{3}$ One important factor appears to be inferior location or site quality, as rapid urbanization pushes new buildings further out along the urban periphery of many Chinese cities. The underlying hedonic traits controlled for in our estimation are described below in more detail.
} 
the hedonic house price index more accurately reflects changes in price appreciation over time in the eight major markets for which we have data for this part of the analysis. The simple hedonic model indicates that house price growth has been very high in virtually all markets.

The plan of the paper is as follows. The next section begins by describing the unique land price data that we amassed for major Chinese markets. Changes in real constant quality land prices are then estimated, along with a description of how quantities changed on the supply side. This section closes with a brief examination of the drivers of the price and quantity change series. Section III then turns to the issue of how best to measure house price changes in an emerging market like China. As just noted, we provide a real, constant quality hedonic price index for newly-built homes in eight major cities and contrast it with the existing official indexes. Section IV concludes.

\section{Land Markets in China: Measurement and Analysis \\ a. Data Collection and Creation of Constant Quality Land Price Indexes}

With very rare exceptions, researchers typically do not have access to data on raw land values because sales of land parcels separately from the buildings on them are seldom observed. ${ }^{4}$ A special feature of the Chinese market is that sales by local governments of the right to use land over long periods of time occur regularly in each city, and have been consistently recorded since 2003. Legally, the Chinese government retains ultimate ownership of all urban land, so what we observe is the transfer of a leasehold interest. A 1988 constitutional amendment allows the purchase of use rights

\footnotetext{
${ }^{4}$ In the U.S. context, Haughwout, Orr and Bedoll (2008) is one counterexample. There are also land transactions observed in Singapore and Hong Kong SAR. See Ching and Fu (2003) and Ooi, Sirmans, Turnbull (2006) for a discussion of land transactions in Singapore and Hong Kong SAR, respectively.
} 
for up to 70 years for residential properties. All future rental payments are included in the upfront price paid by the purchaser, so we treat the initial lump sum payment as the transactions price of the land parcel.

The 2003 start date is due to a May 2002 ruling by the Ministry of Land and Resources (MLR) which required all residential and commercial land parcel leasehold purchases subsequent to July 2002 to be sold via some type of public auction process. ${ }^{5}$ Values since then reasonably can be expected to reflect fair market values. The MLR also requires the local land authority to publicly report the winning bidder and the transactions price. Furthermore, it is standard procedure for the local authority selling the parcel to publish detailed information on the parcel's address, size, designated usage, land conditions on delivery, and major planning indicators such as floor area ratio.

Wu, Gyourko and Deng (2012) were the first to collect these data on land sales for the capital city of Beijing. In this paper, we expand that effort to include information on the 35 major cities depicted in Figure 1. To our knowledge, this is the first comprehensive description of major local land markets in China. More specifically, we worked with Soufun, a leading real estate data vendor in China, to obtain the data for residential land parcel transactions from each local land authority's web site. ${ }^{6}$ Table 1 reports summary statistics on the number of cities covered by year, along with the

\footnotetext{
${ }^{5}$ Prior to this ruling called the $11^{\text {th }}$ Provision, most transactions of urban land parcels were done by negotiation between a developer and a local government. This process was criticized for being opaque and open to corruption. For our purposes, the prices that resulted seem likely to be below free market levels, with the degree unknown and possibly changing over time depending upon local circumstances. Currently, all transactions must be done via public auctions, including regular English auctions (pai mai), two-stage auctions (gua pai), and sealed biddings (zhao biao). See Cai, Henderson and Zhang (2009) for a comparison of these three types of auctions.

${ }^{6}$ Our data exclude parcels wholly designated for public housing units because the pricing mechanism for those sites is different. Public housing programs in China include low-rent units (lian zu fang), public rental units (gong gong zu lin fang), affordable housing units (jing ji shi yong fang) and price-controlled units (xian jia fang). Typically the parcels designated for low-rent units would be directly allocated by local governments, and parcels for price-controlled units are required to transact via public auctions. There is a mixture of possible outcomes for public rental units and affordable housing units.
} 
number of land parcel transactions and the square footage involved. There is complete data dating back to 2003 for 15 markets. Another seven begin in 2004, with the remainder starting more recently. There is an average of about 25 transactions per city in the initial year, with that number ranging typically ranging from about 27 to 50 in subsequent years. ${ }^{7}$

Land parcels in China are priced in terms of the floor area of housing permitted to be built on the parcel, instead of in terms of the land area. Real prices in constant 2009 yuan per square meter of permitted space are computed by deflating with the relevant monthly CPI series for each city. Figure 2 plots the simple means of these real values over time for each market. There is substantial heterogeneity in prices across markets, and one can see the mean reversion that will be documented more formally below. The growing dispersion apparent in this figure is misleading, as it is partially due to the inclusion of added markets over time. For example, if we restrict the analysis to the 15 markets with complete data throughout our sample period, in 2003 land was nearly eight times more costly in the most expensive market (2,693 yuan per square meter of floor area in Hangzhou) than in the least expensive city (352 yuan in Chongqing). By 2011, the gap was just over five times (i.e., with Shanghai at 5,470 yuan and Nanning at 997 yuan). This is not a small absolute difference by any means, but still pales in comparison to the nearly 25 times gap between Shanghai and Wulumuqi (222 yuan) in 2011 for the full sample.

We do not work with the unadjusted transactions prices in the analysis below because the raw means may be driven by quality changes that could arise for a number of

\footnotetext{
${ }^{7}$ We actually observe the specific date of the land sales, but have limited sample sizes at monthly and quarterly frequencies. Hence, our analysis does not investigate higher frequency periods.
} 
reasons. One is that the highest quality sites might be sold first, so that the change in the unadjusted mean values would understate the true constant quality rate of price appreciation. On the other hand, local governments might reserve the good parcels and only list them during the more recent booming periods of the stimulus years, which would result in an overestimation on price growth in the simple average series. In addition, some land parcels were not leveled on delivery in a few cities in the early years of our sample. Not controlling for that would result in the overestimation of true, constant quality price growth. ${ }^{8}$ It also is possible that sales of high quality parcels occur whenever the local government has the greatest need for revenue. Thus, the bias could go in either direction for different markets.

Consequently, we follow Wu, Gyourko and Deng (2012) in creating constant quality land price indexes for each market. Our city-level hedonic is estimated via ordinary least squares (OLS), with the log of the real transaction price as the dependent variable. The explanatory variables include the following: (a) the parcel's distance to the center of the corresponding city $\left(D \_C E N T E R\right)$, which is measured after mapping the precise location of each site with GIS software; (b) the distance to the nearest subway station (D_SUBWAY); this variable is relevant in 10 of the 35 cities with operating subway systems during our sample period; (c) district dummies which control for local/neighborhood-level fixed effects not captured by the two previous location controls; (d) a set of physical attributes including the size of the parcel (in land area; SIZE), the

\footnotetext{
${ }^{8}$ If a land parcel is not leveled on delivery, the purchaser has to pay additional cost for relocating previous occupiers of the parcel, removing the existing buildings, and so forth, which would negatively affect the transaction price of the parcel. Before 2003, whether a parcel was leveled upon delivery was a key part of the negotiation between the developer and the local government. After that, most land parcels sold via public auctions are leveled on delivery, although there were a few exceptions in some cities, especially during the early years. We directly control for this in the hedonic estimation as described below.
} 
density permitted on the site when built $(F A R)$, and whether the parcel is leveled on delivery $(L E V E L)$; (e) in some cases a small portion of a residential land parcel is designated for affiliated commercial properties, public establishments, or public housing units; we control for such conditions via the dummies of COMMERCIAL, PUBLIC and $P H$, respectively; (f) the parcel's transaction form as reflected in whether it was purchased via sealed bidding (BIDDING), regular English auction (AUCTION), or twostage auction (the default group); and (g) year dummies, whose coefficients are used to create the constant quality price index.

Our land price hedonic works at least tolerably well in each of the 35 cities. The coefficients on the quality controls generally are consistent with expectations, and we always can reject the null that there is no explanatory power for our right-hand side variables. Adjusted R-squared values vary from a low of 0.17 (Wulumuqi, whose data begin in 2006) to a high of 0.72 (Fuzhou, whose data begin in 2004). Appendix Table 1 reports some summary statistics on these underlying regressions, all of which are available upon request. ${ }^{9}$ The land price index in each city is constructed from the estimated coefficients of the time dummies, with 2009 as the base year (i.e., year $2009=$ 100). ${ }^{10}$

\section{b. Real, Constant-Quality Land Price Appreciation from 2003-2011}

\footnotetext{
${ }^{9}$ We also conducted a two-stage Heckman estimation to control for potential bias arising from the fact that there were a total of 614 parcels listed that failed to result in transactions (either because there were no bidders if there was an auction or the bid prices were lower than the local governments' reserve prices, which is relevant for cases involving sealed bids). If these failures are disproportionately concentrated in certain periods such as the financial crisis, selection bias would result in an overestimation of the price index for that period. We could not find any statistically significant impact for the inverse Mills ratio estimated from the first-stage probit model.

${ }^{10}$ Average annual appreciation in our hedonic index is about five percentage points higher than in the unadjusted price series, which suggests that parcel quality has been falling over time on average. This does vary by time and market to some extent.
} 
Implied real, constant-quality compounded average annual appreciation rates for each of the 35 cities are listed in Table 2. Among the 22 markets with data back at least to 2004 , there are only two in which constant quality land price growth is appreciating at an average per annum compound rate below 10\% (Nanchang and Qingdao, at 7.8\% and $5.9 \%$, respectively). Nine have experienced average compound annual growth rates above $20 \%$. Naturally, this implies extremely large aggregate growth in real land values. The greatest price appreciation has occurred in Chongqing, which saw prices escalate by 577\% since 2003. The analogous figures for Beijing and Shanghai, respectively, are $336 \%$ and $448 \%$ (since 2003). ${ }^{11}$ Six of the fifteen markets with data back to 2003 have average compound annual growth rates above $20 \%$, which implies their land prices have grown by more than 330\% since then. Qingdao's low 5.9\% per annum average compound growth has led to 2011 prices that are 58\% higher than in 2003.

Summary statistics on the distribution of annual appreciation rates are presented in Table 3. Double-digit average annual price appreciation is the norm, with the simple average across markets only twice being below $10 \%$ and negative only during 20072008. The 34 markets with data for that time period were almost evenly split between those experiencing positive and negative price growth. Even though average real land price growth was slightly positive in 2010-2011, more markets saw price declines than increases that period.

The extremely high volatility of land markets also can be seen in these data. There are very wide swings in the mean appreciation rates across individual years, with evidence of mean reversion at annual frequencies. The average absolute difference in mean price growth rates across consecutive time periods is $24.5 \%$. The swing upon

\footnotetext{
${ }^{11}$ Hefei's real land values grew by an even larger $531 \%$ since 2004 .
} 
entering the global financial crisis from 2006-07 to 2007-08 was -51.7 percentage points, and the decline from 2009-10 to 2010-11 following the end of the stimulus was -28.8 percentage points. The gaps between the highest and lowest appreciating markets within any given year also are extremely wide. Those differences range from 60 percentage points in 2003-04 to 165 percentage points in 2005-06. While most markets tend to move in the same direction within any one year, individual cities can and do experience outsized booms and busts at given points in time. And, there generally are a handful of local markets in which land prices fall in any given year.

Table 4 provides additional insight into just how volatile land prices have been in Chinese cities. Given that land is the residual claimant on property value in standard models, we would expect it to be more volatile than house prices overall. The top panel of Table 4 compares simple mean growth rates of land and house prices in our sample of cities, along with similar measures for construction costs and wages in the construction industry. ${ }^{12}$ The bottom panel then reports the annual standard deviations of those variables.

Land price appreciation well exceeds overall house price growth in all but two years: 2008 and 2011, when we estimate that land prices either dropped or stagnated, while house prices increased modestly. In contrast, construction costs were fairly stable over our sample period, with the highest rate of cost growth being $6.8 \%$ in 2008 . Construction wages grew by more on average in each year, but wage growth still pales

\footnotetext{
${ }^{12}$ The house price growth rate is derived from the constant quality price index for newly-built house units, which will be described in detail in Section III. Construction costs and wages in the construction industry are both reported by the National Bureau of Statistics of China (NBSC); since no city-level statistics are available for these two series, the series in the corresponding provinces in which the cities are located are adopted instead. All four series in Table 4 are in real terms and are deflated by the CPI index in each city. Construction cost and wage data for 2011 are not yet available.
} 
compared to that of land price appreciation. Standard deviations in land prices range from $22 \%-42 \%$, depending upon the year, so the volatility is quite high. These magnitudes are 3-4+ times the standard deviation of any other factor price reported in the table.

Figure 3 plots each city's log index value, with the price in 2009 set to 100. Figure 4 then plots real land price appreciation rates for the same set of cities. Here, one begins to see the common movement in price growth across markets. The strong influence of a common, national effect on city-level land price appreciation is more evident from simple regressions of annual price appreciation rates on year dummies and city dummies. Table 5 reports summary statistics from city and year fixed effects regressions. Year dummies alone can account for $24 \%$ of the variation in annual land price growth in the 35 markets depicted in Figure 4. This is more than four times the $\mathrm{R}^{2}=5 \%$ arising from a regression on city dummies alone. And, one cannot reject the null hypothesis that the city fixed effects jointly equal zero. These factors are largely orthogonal to one another, as including them together yields a $\mathrm{R}^{2}=0.28$. Thus, some common, national effect can account for over one-fifth of the variation depicted in Figure 4, while there does not appear to be any fixed city trait that can explain much of it.

This raises the question of whether there are time-varying local market characteristics which can explain the variation in land price growth. To investigate this, we created a number of variables that reflect demand, supply and credit conditions in each market. The demand for residential land is derived from the demand for housing itself, so one variable is a measure of the supply-demand balance in the housing market $\left(\right.$ hsdratio $\left.{ }_{i, t}\right)$. More specifically, it is the ratio of the floor area of newly-built housing 
listed in city $i$ and year $t\left(\right.$ hlisted $\left._{i, t}\right)$ to the floor area of newly-built housing that was sold in the same city and year $\left(h\right.$ sold $\left._{i, t}\right)$, as defined here:

(1) ssdratio $_{i, t}=$ hlisted $_{i, t} /$ hsold $_{i, t}{ }^{13}$

In the regression model estimated below, we introduce the one year lagged term, hsdratio $_{i, t-1}$, in order to avoid potential reverse causality. This variable should be negatively correlated with the change in local land prices, as a higher value of this ratio indicates increasing oversupply in the housing market.

We also control for expected nonfarm employment growth in the city using a variable akin to the one developed by Bartik (1991). This variable, epgrowth $_{i, t}$, is calculated as the weighted average of national industrial sector employment growth rates, where the weights reflect each city's share of that industry's aggregate employment. More specifically,

(2) epgrowth $_{i, t}=\sum_{j=1}^{18} \frac{e_{i, j, t-1}}{e_{i, t-1}} \cdot\left(\frac{\tilde{e}_{i, j, t}-\tilde{e}_{i, j, t-1}}{\tilde{e}_{i, j, t-1}}-\frac{e_{t}-e_{t-1}}{e_{t-1}}\right)$ where $e_{t}$ is the national employment level in all nonfarm industries, $e_{i, j, t}$ is city $i$ 's employment in industry $j$ in year $t, \tilde{e}_{i, j, t}$ is the national employment level in industry $j$ outside of city $i$, and the $j$ subscript indexes the 18 nonfarm employment sectors in China. ${ }^{14}$ This variable should be positively correlated with the change in local land prices, as it is close to being a pure demand shifter.

In the U.S., credit markets are thought by many to have played a prominent role in helping generate the stark rises in housing markets seen in many markets. For China, we

\footnotetext{
${ }^{13}$ The numerator and denominator are based on data provided by the Ministry of Housing and Urban-Rural Development (MHURD). Each reflects activity permitted by a local housing authority. This variable is only available through 2010 .

${ }^{14}$ All employment data are from the National Bureau of Statistics of China (NBSC). Because industrial classifications were adjusted in 2003, this variable is available in a consistent format beginning in 2004. Currently the data are only available through 2010 .
} 
proxy for local credit market conditions with the amount of new loans issued to developers by year in each market, denominated in billions of 2009 yuan. ${ }^{15}$ The specific measure used in the regression analysis below is developloan $3 y r_{i, t}$, which is the lagged, three-year average of these loan amounts (i.e., the average for the three years from t-3 to t-1). This variable is expected to be positively correlated with changes in local land prices to the extent that better liquidity conditions in the local property market allow developers to bid up land prices.

To see if time-varying local market conditions influence land markets, the log change in the individual market land price indexes is regressed on these factors plus year dummies in a random effects estimation as follows:

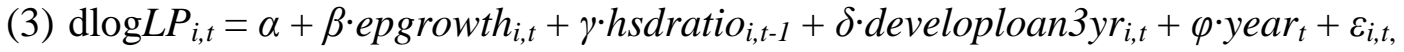
where $\operatorname{d} \log L P_{i, t}$ is the $\log$ change in city $i$ 's annual land price index and all other variables are as described above. ${ }^{16}$ The results are reported in the first column of Table 6 . Note that this table only uses data through 2010 because that is the latest year available from some regressors.

Each coefficient has the expected sign, with those on the supply-demand conditions and liquidity measures being statistically significant at standard confidence levels. The expected employment growth variable is significant at the $12 \%$ level (tstatistic $\approx 1.6$ ). The second column of the table augments this baseline specification by including interactions of each local trait with the time after 2008 (i.e., years 2009 and 2010) which capture the period after the global financial crisis began and China instituted its massive stimulus program. Here, we see that virtually all of the impact of the time-

\footnotetext{
${ }^{15}$ Source: National Bureau of Statistics of China (NBSC).

${ }^{16} \mathrm{We}$ also experimented with directly controlling for city fixed effects. The standard Hausman test indicates the random effects specification is preferred. In any event, the results are not materially affected.
} 
varying local traits is due to variation in the years prior to the Chinese stimulus. While caution is in order given the limited degrees of freedom involved, we cannot find any local trait that is strongly correlated with land price changes in a statistical or economic sense during the stimulus period. ${ }^{17}$

In one sense, it is comforting to know that our proxies for local market

fundamentals and credit conditions work as any simple economic model would predict, especially given the limited time series over which we can estimate the relationships. ${ }^{18}$ However, it still is the case that these effects are small relative to the impact of the common national effects reflected in the coefficients on the year dummies. On average, the typical 'year effect' is about 30 percent, which is roughly equal to the standard deviation of the log change in annual land prices for the cities in our sample. Thus, local land price appreciation has been driven much more in recent years by a common, national effect than by local market factors. This suggests that changes in sentiment about the

\footnotetext{
${ }^{17}$ Even prior to the stimulus, the economic importance of these traits is limited. Computing standardized marginal effects of the three local characteristics using the coefficients from column 2 of Table 6 yields the following: (a) a one standard deviation increase in expected employment growth in a city is associated with one-fifth of a standard deviation increase in its log change of land prices; (b) a one standard deviation increase in the ratio of floor space listed relative to that sold in a market in the previous year is associated with half of a standard deviation lower log change of local land prices; and (c) a one standard deviation increase in the lagged average of developer loans in the city is associated with about one-tenth of a standard deviation increase the log change in land prices.

${ }^{18}$ We experimented with other local traits, but they were insignificant and/or did not change the basic tenor of the results reported in Table 6. For example, we also collected data on local infrastructure investments related to transportation, environmental projects (e.g., drainage, purification, gardening and greening), and so-called basic infrastructure (e.g., water supply) as reported by the Ministry of Housing and Urban-Rural Development of China (MHURD). Those measures are highly positively correlated with our developer loan variable ( $\rho$ ranges from 0.77 to 0.86 depending upon the specific infrastructure measure). Including one of these infrastructure variables in lieu of our credit market proxy yields very similar results to those reported in Table 6. We also developed a measure of expected time on the market using data on local housing inventory and the amount of sales. This variable is positively correlated with our supply-demand ratio, and has no influence independent of hsdratio. However, it is correlated with log land price changes in the expected way. This highlights that our goal here is not to claim some type of tight casual relationship for a specific variable. We have too short a time frame and lack plausibly exogenous variation for such a convincing analysis. Rather, our point is to note that there are various local traits that plausibly capture fundamental conditions which are correlated with land price appreciation in ways that a simple economic model would predict.
} 
country's economic prospects will influence local land markets more than will the supply-demand fundamentals of those markets themselves.

One other noteworthy feature of Figure 4's plot of annual land price appreciation is the apparent mean reversion in the series. Table 7 reports results from very simple models of the log change in current land price appreciation on lagged appreciation, controlling for time and city fixed effects (in most cases). One does not want to make too much of these findings given the limited time series (and the fact that we do not have data over a complete housing cycle), but the findings confirm the visual impression delivered by Figure 4. Essentially, if land price growth is 1 percentage point higher this period, it is about $0.35 \%$ lower next period (column 1 ). This is quite different from what researchers have found in the housing market in U.S., where there is strong persistence in housing price growth across years and mean reversion over longer periods such as five year intervals (e.g., Case and Shiller (1987), Cutler, Poterba and Summers (1991), Glaeser, et. al. (2010)).

This naturally raises the questions of why this pattern exists in the data, and whether the volatility in the land market provides useful information to understand housing market movements. We do not answer that question here, but Table 8 provides some intriguing insight into one possible factor. The Chinese government is known to intervene in the housing market, especially to tame it. For instance, when housing markets in some coastal-region cities started to boom in 2004-05, the central government issued a series of intervention policies between late 2005 and early 2006 to cool the market. Similar patterns also apply to the cases of intense interventions in late 2007, whose effect was later intertwined with the unexpected global financial crisis, and most 
recently in the second half of 2010. The stimulus following the U.S. financial crisis is a counterexample of intervention to boost the market. Besides the huge stimulus package, in December 2008 the central government also unfolded several measures focusing on the real estate sector for the purpose of encouraging housing consumption (State Council Degree, No. [2008]131), which at least partially may have fueled the skyrocketing house prices and land prices in 2009.

The results in Table 8 lend credence to a role for government in its specifications, the first of which interacts the lagged land price appreciation term with a dummy variable indicating the direction of land price growth in the previous year. The results indicate that mean reversion is larger if land prices were increasing in the previous year.

Subsequent specifications in the table investigate whether local fiscal conditions also might have played a role. Those specifications include a triple interaction that includes the size of the local fiscal deficit in the previous year. The variable, deficit $t_{i, t}$, is calculated as the ratio between local budgetary fiscal expenditure and budgetary income in city $i$ and year $t$, or more specifically,

$$
\text { (4) } \text { deficit }_{i, t}=\operatorname{bexp}_{i, t} / \operatorname{binc}_{i, t}
$$

where $b \exp _{i, t}$ is city $i$ 's budgetary fiscal expenditure in year $t$, and $b i n c_{i, t}$ is the budgetary fiscal income. In the analysis, deficit ${ }_{i, t}$ serves as the proxy of local government's fiscal pressures and reliance on land sales. ${ }^{19}$ The coefficients on that term are not statistically significant at standard confidence levels, but the sign is such that mean reversion from

\footnotetext{
${ }^{19}$ In China, local governments' fiscal income mainly comes from two sources: budgetary income from local tax, and off-budget income, most of which is from land sales. Under the current "tax revenue sharing system" established in 1994, local governments could only retain 40-50\% of the budgetary income, but are burdened with $70-80 \%$ of the budgetary expenditure, which imposes heavy fiscal pressure for them. Consequently, local governments have to rely on land sales as a major off-budget fiscal income source. In 2010, total land sales income reached 2914.7 billion yuan nationally, equaling $74.1 \%$ of local governments' budgetary income (Ministry of Finance of China). See Tsui (2005) for more details about the public finance system in current China.
} 
price growth booms is smaller if the local government has been running larger deficits. Perhaps those governments have less of an incentive to actively implement any countervailing policies emanating from the central government in Beijing. In contrast, when price growth has been falling, such cities might have an incentive to be especially aggressive in reversing the decline in prices, which would lead to the larger mean reversion effect from such periods. The pattern of these results is consistent with this expectation, although it is at most marginally significant. We certainly have not established any causal relationships here, but this does serve to illustrate the potential usefulness of a rich panel of observations on local land markets.

c. Stylized Facts about Quantities: The Volume of Land Sales, 2003-2010

Figure 5 plots the floor area sold by year across our sample of markets, with Table 9 reporting summary statistics on the amount of space supplied. Note that the supply of space has increased greatly, and this is not solely due to the rise in the number of cities covered in our sample. The aggregate supply of space has roughly doubled just since 2008, when all 35 cities are included in the sample. Figure 5 also depicts some convergence in the flow amount of new space supplied across markets over time. ${ }^{20}$

Table 10 reports results analogous to those above in Table 5 as to whether this movement in supply can be explained by city-level or national fixed effects. Both factors are empirically relevant, although city fixed effects can explain more of the variation. It is not surprising to find significant city fixed effects here, as the amount of space supplied certainly is linked with market scale. However, there are statistically and economically

\footnotetext{
${ }^{20}$ There is a similar convergence if we restrict the sample to the 15 markets for which we have consistent data back to 2003 .
} 
meaningful year effects, so we cannot reject the null hypothesis of a strong common or national effect in new supply.

Table 11 reports some simple regressions to see if time-varying city traits can explain any of the variance in the supply series. Here, besides the city and year fixed effects, we introduce two local politics variables. One measures the degree of budgetary deficit in the previous year as defined above, and the other measures the length of time (in years) that the top local Chinese Communist Party (CCP) officer has been in his (or her) position. The results in column 1 of this table show that if the city government was spending a lot relative to its revenues last year, it was likely to sell more land this year. In addition, more land gets supplied the newer the top Communist Party leader is in the local government. ${ }^{21}$ While these should be viewed as simple correlations because we have no causally identifying variation, the results strongly suggest that local political economy considerations probably play an economically meaningful role in land supply. The second column of Table 11 includes interaction terms with the stimulus period of 2009-2010. Both coefficients are positive, but neither has a t-statistic above 1. Columns 3 and 4 then investigate whether current deficit situations (not just lagged ones) are correlated with supply conditions (this variable is only available through 2010). The answer is yes, and the finding that CCP officers new to their offices sell more land is robust to these changes in specifications.

In sum, city and year fixed effects can explain about $60 \%$ of the variation in the supply of new space annually in our 35 market sample. Local political economy factors

\footnotetext{
${ }^{21}$ Other research suggests that performance in boosting local economic growth is a key determinant of local officers' career path in China ( $\mathrm{Li}$ and Zhou, 2005). The newly appointed officers are strongly incentivized to expand government expenditure or investment to build political capital for their future promotions, and thus generate higher demand for fiscal revenues.
} 
also appear to be empirically relevant, as the fiscal balance of the city and whether the local CCP chief is new to his or her job also are correlated with supply.

\section{d. Some Comments on Very Recent Changes in Chinese Land Market Data}

The widespread, but not universal, declines in real constant quality land prices in 2011 are similar in nature to what happened in 2008 as the global financial crisis unfolded. Nineteen markets saw real land values fall in 2011 versus sixteen in 2008. Those earlier period declines were quickly reversed by the massive Chinese government stimulus in 2009 and 2010. Only time will tell if something similar occurs this time.

There still is substantial heterogeneity across markets, even in the most recent data, so it remains inaccurate to claim that there is some single national Chinese land or property market. Sixteen markets still experienced positive land price appreciation in 2011, with nine of them having double-digit price growth (and each of these nine were in the interior of the country). ${ }^{22}$ There were some very big price declines in 2011 , too, with 10 of the 19 decliners experiencing double-digit drops. Many of these markets were along or near China's coast. ${ }^{23}$

We have also collected data for the first quarter of 2012. These city-level samples are small, so we do not report price index or change data based on them. However, there are stark falls in transactions volume, whether measured by the number of parcels sold or by the permitted square footage on those parcels. Using the latter metric, 2012(1) volumes are $65 \%$ of $2011(1)$ levels and $46 \%$ of $2010(1)$ levels, on average. In only 6 of

\footnotetext{
${ }^{22}$ Those markets are Changchun (30.8\%), Changsha (59.8\%), Chongqing (21.2\%), Haerbin (18.1\%), Huhehoate (108.6\%), Wuhan (13.6\%), Xian (14.0\%), Xining (62.4\%), and Zhengzhou (16.1\%).

${ }^{23}$ The biggest decliners were Beijing (-44.2\%), Fuzhou (-27.7\%), Guangzhou (-43.0\%), Shanghai ($18.0 \%)$, and Qingdao (-16.6\%). The other coastal markets of Dalian, Ningbo, Hangzhou, Shenzhen and Xiamen were either flat or slightly negative.
} 
our 35 markets is permitted square footage on sold parcels in the first quarter of 2012 greater than that in the first quarter of 2011; the analogous number when comparing 2012(1) to 2010(1) is seven ${ }^{24}$. Twenty-one of the 35 markets (or $60 \%$ of our sample) have 2012(1) permitted square footage levels that are at least 50\% below 2010(1) levels prevailing in the final year of the stimulus. The changes here are especially stark among the coastal markets: Beijing's numbers are down $75 \%$; Shanghai's are down $91 \%$; Fuzhou's are down 96\%; Dalian's are down 92\%; Qingdao's are down 91\%; Ningbo's are down 89\%; Guangzhou and Xiamen had no land sales in 2012(1), so there levels are down $100 \%$. These percentage changes are not artificially high because of the comparison with the 2010(1) stimulus period. Twenty-two of our 35 markets have permitted square footage on sold land parcels in 2012(1) that are more than 50\% below their 2011(1) levels.

In sum, transactions volumes in the land market have plummeted in most (but not all) major Chinese cities. This suggests that demand by private developers is very low. It is well known that house prices around the world do not follow a random walk and tend to be sticky downward with quantities falling before prices do. If this is the case in China, then these most recent transactions data are foreboding and bear close scrutiny going forward. If they do not reverse to a significant extent, one would expect sharp price declines in the near future.

III. What Is the True Level of Housing Price Growth in China? Measurement and Analysis

\footnotetext{
${ }^{24}$ Only Changsha, Changchun, Chengdu, Jinan, Wuhan, Yinchuan and Zhengzhou have 2012(1) permitted square footage levels above those during the 2010(1) stimulus period.
} 
Measuring house price growth may seem like a straightforward matter given the now widespread acceptance of the repeat sales methodology reintroduced and popularized by Case and Shiller $(1987,1989) .{ }^{25}$ However, it is not so in China (and other emerging markets), where a significant portion of the housing stock consists of new (or relatively new) housing units that have not yet been sold multiple times. Obviously, a repeat sales index captures price changes of existing homes, which by definition are the only ones that have been sold more than once.

China reports two house price series, each of which is based exclusively on the values of newly-built housing units. According to statistics published by Ministry of Housing and Urban-Rural Development of China, 64\% of all the floor space in units transacted in 2010 was from newly-built units, so accurately measuring the price change on new units captures much of the variation in the value of entire housing stock in China. ${ }^{26}$ One series is the called the Average Selling Price of Newly-Built Residential Index. It reflects the simple average of transactions prices (total sales values divided by total size of housing unit transacted) on new housing units, and is based on statistics reported by all developers in each market. It makes no attempt to control for any quality differentials across markets or drift (positive or negative) in housing units over time. It is available for all markets across China. The other series, which is officially termed "Price Indices in 70 Large and Medium-Sized Cities" (or "70 Cities Index" for short), is a measure of changes in average prices on units sales within individual housing complexes over sales stage or time periods. More specifically, this index is calculated by first

\footnotetext{
${ }^{25}$ Their work is based on the seminal contribution of Bailey, Muth and Nourse (1963).

${ }^{26}$ Ideally, one would like to capture price changes on existing homes, too, but the reported transactions prices of existing units presently are not considered of high quality in China, at least partially because an unknown number of people are reporting lower values to avoid transaction taxes and capital gain taxes.
} 
computing the average sales price of new units each month, by housing complex. The monthly series then is the transactions volume-weighted average of each complex's average price changes over time.

Figure 6 plots each series for the eight major markets reported in $\mathrm{Wu}$, Deng and Gyourko (2012) between 2006 Q1 and 2010 Q4, ${ }^{27}$ with Table 12 reporting the implied average compound price growth for each series over our sample period. There are two noteworthy features of these data. First, data from the "70 Cities Index" never shows much price appreciation in any of the eight major markets. In some but not all of these cities, the simple average price index also exhibits relatively little growth and volatility. Second, the two series are not highly correlated with one another.

If these data are to be believed, the "70 Cities Index" in particular sends a comforting message about the state of housing markets in major Chinese cities, in that it does not indicate there has been a great boom that might have led to substantial overpricing (relative to underlying fundamentals) of house prices in these places. However, Wu, Deng and Liu (2011) provide good reasons to believe these series are biased downward, possibly quite substantially. For example, it is well known that price growth calculations based on simple averages will overstate (understate) the true change in constant quality values to the extent that quality rises (falls) over time. To determine the extent of heterogeneity across markets and quality drift over time, one must go to the data.

The continuous suburbanization of sites as urban growth has skyrocketed in major Chinese cities means that new units are being produced in housing complexes farther

\footnotetext{
${ }^{27}$ The average price index started in the mid-1990s, and the "70 Cities Index" began in 1997. Both indexes significantly adjusted their coverage or estimation method in the second half of 2005 . Hence, we display each series here only since 2006 Q1.
} 
away from the urban core. Using data on an anonymous Chinese market, $\mathrm{Wu}$, Deng and Liu (2011) report that the average distance from the city center increased by $50 \%$ just between 2004 and 2007 (i.e., from 4.2 kilometers to 6.1 kilometers). If this is typical of most rapidly growing markets, then location quality has changed a lot in recent years. In the U.S. context, this would not be a signal of lower quality, as sorting into suburban sites often is associated with higher location quality, particularly as higher income households sort into homes located in high quality school districts. There is no reason to expect any such spatial sorting in China, and Wu, Deng and Liu (2011) report results from a hedonic house price regression (see below for more on their model and the hedonic approach) indicating that not controlling for the fact that new housing units are being built farther out from the urban core is associated with over a $14 \%$ underestimation of constant quality prices. Hence, the rapid growth in urban Chinese markets is associated with units being built on lower quality sites, and not controlling for this feature results in a meaningful underestimation of constant quality price growth over a period as short as three years. ${ }^{28}$

Increasing density is another trait of new housing complexes that suggests quality has deteriorated over time. Based on data from various issues of the Statistics Yearbook of China, Wu, Deng and Liu (2011) calculate that permitted floor area ratios (FAR) increased by over $60 \%$ between 2000 and 2010 (i.e., from 2.15 in 2000 to 3.57 in 2010). Their hedonic analysis using micro data on an unnamed Chinese housing market does not indicate this severely depresses prices, but increasing density is considered a disamenity

\footnotetext{
${ }^{28}$ That said, accurately controlling for this trait is difficult in a period of extremely high growth. If the true center of activity is changing, we would expect an unchanging noisy measure to lead to a downwardlybiased hedonic price.
} 
in any reasonable housing or urban model, so it is yet another reason why the two government indexes might understate true price growth, all else constant. ${ }^{29}$

Strategic pricing behavior by developers is yet another reason why the second "70 Cities Index" might substantially understate true house price appreciation. As Wu, Deng and Liu (2011) argue, the tradeoff between setting a higher price and the carry costs of unsold units as reflected in their time on the market is likely to lead developers to price their units so the last units sold are of lower price. In their empirical analysis using data from the same anonymous Chinese housing market, they provide results from a hedonic regression consistent with this conclusion, as the last unit sold in a typical housing complex goes for $11 \%$ less than the first unit from the same complex. Thus, not being able to control for the timing of sales, which the "70 Cities Index" does not do, is likely to lead to substantial underestimation of the true price increase.

Even if individual housing unit quality has not deteriorated over time (and it could have increased), all this suggests that the quality of the housing complexes in which the units are located has fallen over time, at least partially because of their inferior locations. ${ }^{30}$ Not being able to control for this downward quality drift means that both

\footnotetext{
${ }^{29}$ The ceteris paribus assumption is critical here, of course. Increasing density may bring other benefits such as more and better restaurants, improved infrastructure, and the like. The entire package could result in higher overall quality for a given location. However, we are concerned here with the direct impact of more structure on a given amount of land. That is a disamenity and the direct effect should be to lower prices. The hedonic model by Wu, Deng and Liu (2011) also suggests a significantly negative effect of high density.

${ }^{30}$ The vast majority $(95 \%+)$ of new housing units are situated in condominium-like high rise complexes according to recent issues of the Statistics Yearbook of China. The rest are so-called landed houses, by which is meant the units are detached or attached and sited on their own plots of land. In this report, we focus exclusively on the former type of housing unit.
} 
indexes reported by the government underestimate the true extent of house price growth. $^{31}$

Therefore, we apply the hedonic estimation approach to the eight major cities reported by Wu, Gyourko and Deng (2012). All the newly-built housing units transacted between 2006 and 2010 in these cities are included in the calculation. ${ }^{32}$ The resulting series and their real average compound growth rates are also reported in Figure 6 and Table 12. There are two noteworthy features of the comparison between this constant quality index and the two existing official indexes. First, in each of the eight cities the hedonic indexes grow much faster than the "70 Cities Index". The deviation from the real average compound price growth rates varies from 1.71 percentage points in Wuhan to 4.93 percentage points in Beijing. This implies that the bias arising from the strategic pricing behavior by developers in the newly-built markets is important. The "70 Cities Index", which presently is the most influential house price indicator in China, appears to be fairly unreliable in terms of reflecting price changes over time. ${ }^{33}$

The relationship between the hedonic index and the average selling price is mixed. The average compound growth rate of the hedonic index is higher in the cities of Beijing, Shanghai, and Xian, but fairly similar in Tianjin, Hangzhou, Wuhan, and Shenzhen. In Chengdu, the average price index grew faster than the hedonic price index during the sample period. As suggested above, the key potential bias facing the simple average

\footnotetext{
${ }^{31}$ Technically, the bias results because omitted quality change that is reflected in the residual of the price estimation equation is negatively correlated with estimated price change (i.e., because quality is falling over time). See $\mathrm{Wu}$, Deng and Liu (2011) for a derivation.

${ }^{32}$ In the calculation, all the units transacted in the sample period in one city are pooled in a hedonic model. After controlling for the major locational and physical attributes, the hedonic price index is calculated based on the time dummy coefficients. See Wu, Deng and Liu (2011) for the example in one city and more details about the calculation process.

${ }^{33}$ NBSC regularly updates and reports the "70 Cities Index" each month. But in most cities, NBSC does not directly report the average price, but the aggregated transaction volume and its total value only. Therefore, the former series is much more well-known to the public.
} 
method is due to quality shifts of transacted units, whose effects would vary with time and city. In general, the eight cities covered here are the most developed cities in China, in which the process of urban expansion started earlier and thus has slowed in recent years. Comparably, the effect of urban expansion in the average price index would be more important in the emerging cites. Even though it seems that the bias in the average price index in these eight major markets would not significantly affect our judgment of their market conditions during the sample period, we still would not want to extrapolate that conclusion to other markets or to the national level. ${ }^{34}$

Another difference is that the average price series is always more volatile than the hedonic price index, which at least partially results from the fluctuation of sold units' quality. This effect is especially important in relatively small markets such as Shenzhen and Xian, and will make the change of the average price index in specific periods less reliable (for example, the sharp fluctuation of the average price index in Shenzhen in 2009 and 2010). Even in large markets like Beijing and Shanghai, such an effect could also lead to very different results in some periods like late 2010.

\section{Summary and Conclusions}

This paper reports the first results and summary statistics on conditions in Chinese land markets using new data based on auction sales from 2003-2011 in 35 major cities. While there is meaningful heterogeneity in land price growth across markets, on average the last nine years have seen land values skyrocket in many markets, not just those on the

\footnotetext{
${ }^{34}$ As calculated by Wu, Deng and Liu (2011), the real average growth rate of the aggregated average price index in 35 major cities was significantly lower than that of the hedonic price index $(1.87 \%$ and $3.94 \%$, respectively).
} 
coasts. The typical market has experienced double-digit compound annual growth in real values on average.

Three notable characteristics about the land value appreciation series are its strong mean reversion at annual frequencies, the strong common factor in its movement, and its very high volatility. Mean reversion is about $35 \%$ across years. Year dummies account for just over one-fifth of the variation in the data, while city fixed effects are not statistically significant. Volatility is quite high, and a comparison with other factors of production used in housing shows that the volatility in house prices is being driven by the land market, not construction costs or construction sector wages.

Quantities, not just prices, have been sharply increasing in recent years. The typical amount of space supplied has doubled since 2008. Flow supply is better explained by city fixed effects, although there is some common, year effect, too. Local political economy factors can account for some of the time series variation over time within cities on the supply side.

We also investigated the quality of the two most prominent house price indexes in China, and concluded that a traditional hedonic index would more accurately reflect how house prices have changed over time in eight major markets in China. Repeat sales indexes have become standard in many markets, but they are not as useful in emerging markets such as China because the bulk of the housing stock is relatively new and has not traded multiple times. China's most prominent index which reflects changes in the averages of sales values within a housing complex over time shows very little volatility and limited overall price appreciation. It appears to suffer from severe downward bias for the reasons discussed in $\mathrm{Wu}$, Deng and Liu (2011). A simpler average price index 
also published in China shows marked rises in some markets, but not in others. It appears most biased where quality change has been the greatest—which tends to be in the smaller and emerging markets. We conclude that simple hedonic indexes that can control for basic unit traits, as well as location quality of the housing complex in which it is situated, more accurately capture changes in house prices over time in most markets. Those series show very high house price appreciation over time and appear to more accurately reflect the path of prices in Chinese markets.

We believe these data will serve as the foundation for much broader and in-depth future work on Chinese land and housing markets. There is much more to be done in investigating how local market traits might better explain the time series variation documented here. Other potentially important questions include whether changes in local land markets are good predictors of what will happen to housing prices in the future and whether there is an economically important collateral channel effect on non-real estate sector firms through the Chinese finance system. 


\section{Selected References}

Bailey, Martin, Richard Muth and Hugh Nourse (1963). "A Regression Method for Real Estate Price Index Construction." Journal of the American Statistical Association, Vol. 58, No. 304: 933-942.

Bartik, Timothy (1991). Who Benefits from State and Local Economic Development Policies? Kalamazoo: Upjohn Press.

Cai, Hongbin, Vernon Henderson, and Qinghua Zhang (2009). "China's Land Market Auctions: Evidence of Corruption,” NBER Working Paper \#15067.

Case, Karl and Robert Shiller (1987). "Prices of Single Family Homes Since 1970: New Indexes for Four Cities," New England Economic Review, Sep/Oct: 45-56.

Case, Karl and Robert Shiller (1989). "The Efficiency of the Market for Single-Family Homes," American Economic Review, Vol. 79, No. 1: 125-137.

Ching, Stephen and Yuming Fu (2003). "Contestability of the Urban Land Market: An Event Study of Hong Kong Land Auctions," Regional Science and Urban Economics, Vol. 33, No. 6: 695-720.

Cutler, David, James Poterba and Lawrence Summers (1991). "Speculative Dynamics," Review of Economic Studies, Vol. 53, No. 3: 529-546.

Glaeser, Edward, Joseph Gyourko, Eduardo Morales, and Charles Nathanson (2010). "Housing Dynamics," working paper, October 2010.

Haughwout, Andrew, James Orr and David Bedoll (2008). "The Price of Land in the New York Metropolitan Area," Current Issues in Economics and Finance, Vol. 14, No. 3: 1-7.

Li, Hongbin and Li-an Zhou (2005). "Political Turnover and Economic Performance: The Incentive Role of Personnel Control in China," Journal of Public Economics, Vol. 89, No. 9/10: 1743-1762.

Ooi, Joseph, C.F. Sirmans and Geoffrey Turnbull (2006). "Price Formation Under Small Numbers Competition: Evidence from Land Auctions in Singapore," Real Estate Economics, Vol. 34, No. 1: 51-76.

Tsui, Kai-yuen (2005). "Local Tax System, Intergovernmental Transfers and China's Local Fiscal Disparities," Journal of Comparative Economics, Vol. 33, No. 1: 173-196.

Wu, Jing, Yongheng Deng and Hongyu Liu (2011). "House Price Index Construction in the Nascent Housing Market: The Case of China," National University of Singapore, Institute of Real Estate Studies Working Paper Series, IRES2011-017.

Wu, Jing, Joseph Gyourko and Yongheng Deng (2012). "Evaluating Conditions in Major Chinese Housing Markets," Regional Science and Urban Economics, Vol. 42, No. 2: 531-543. 


\section{Figure 1: Land Market Dataset Coverage}

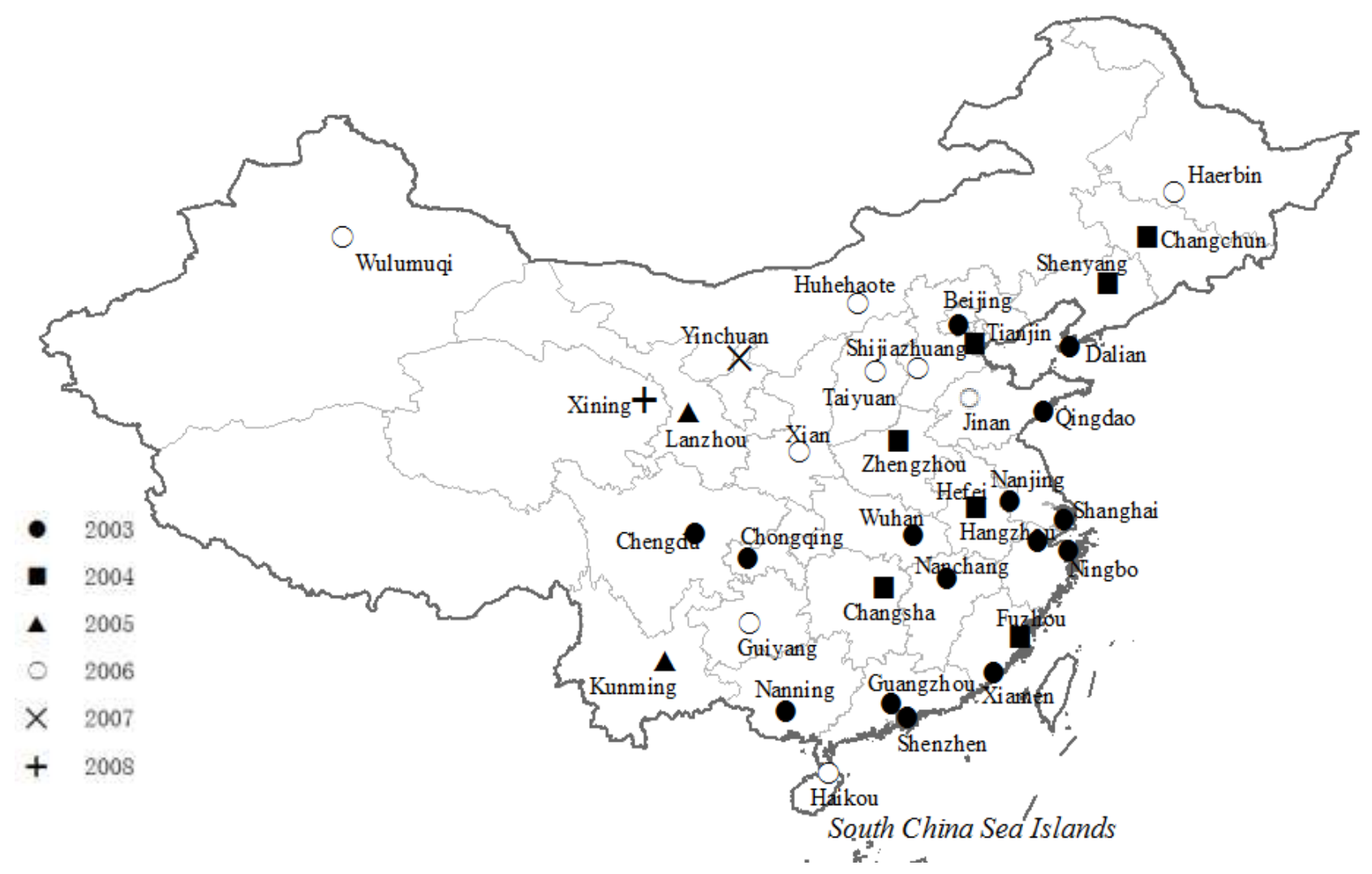

Note: the cities are labeled by the starting year of the land data in the dataset. 
Figure 2: Real Average Residential Land Prices in 35 Major Chinese Markets (2009 Yuan)

yuan per sq.m. of floor area

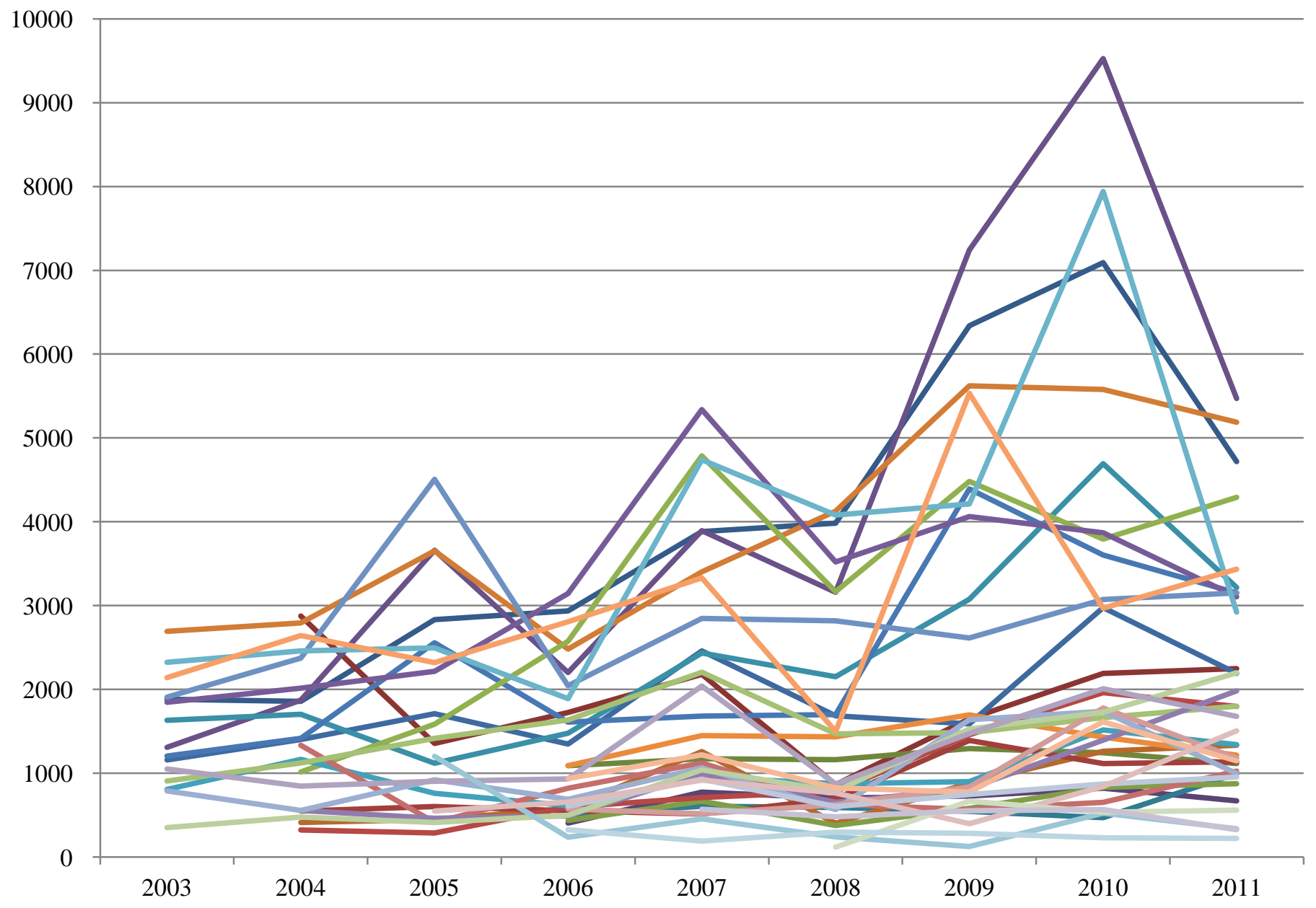

\begin{tabular}{l} 
Beijing \\
Tianjin \\
Shijiazhuang \\
\hline Taiyuan \\
Huhehaote \\
Shenyang \\
Dalian \\
Changchun \\
Haerbin \\
Shanghai \\
Nanjing \\
Hangzhou \\
Ningbo \\
Hefei \\
Fuzhou \\
Xiamen \\
Nanchang \\
Jinan \\
Qingdao \\
Zhengzhou \\
Wuhan \\
Changsha \\
Guangzhou \\
Shenzhen \\
Nanning \\
Haikou \\
Chongqing \\
Chengdu \\
Guiyang \\
Kunming \\
Xian \\
Lanzhou \\
Xining \\
Yinchuan \\
Wulumuqi \\
\end{tabular}


Figure 3: Log Real Land Price Index, 35 Chinese Cities, 2003-2011

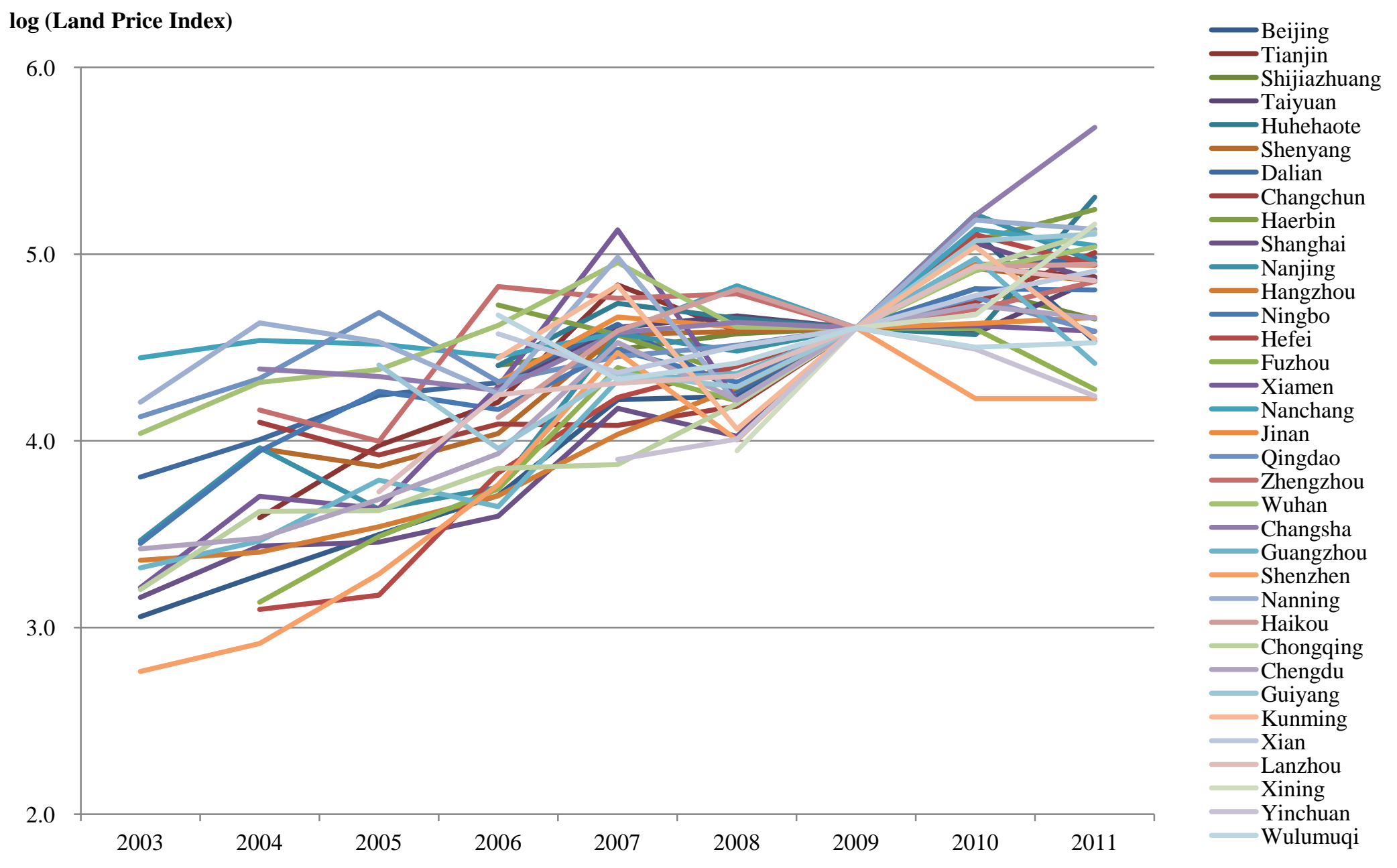


Figure 4: Real Land Price Appreciation by Year, 35 Chinese Cities, 2003-2011
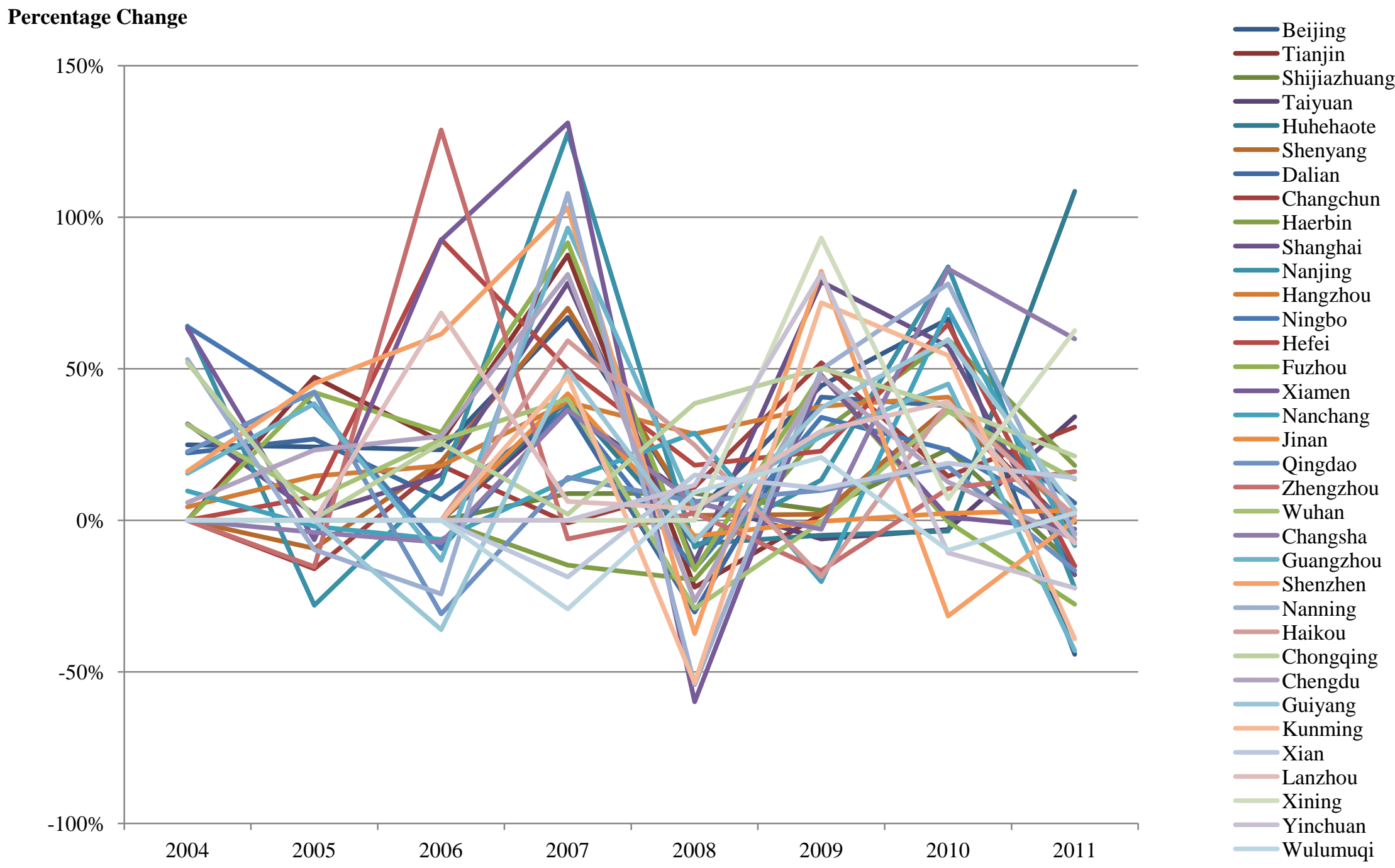
Figure 5: Floor Area Sold by Year, 35 Chinese Cities, 2003-2011 (millions of square meters)

Floor Area

(millions of square meters)

Beijing

30

25

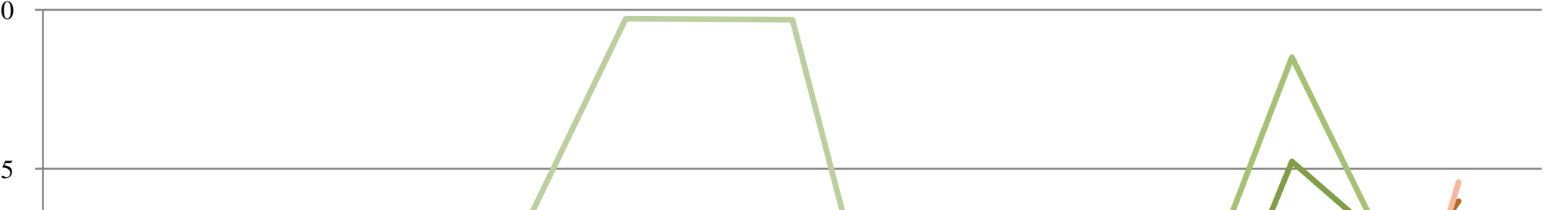

20

15

10

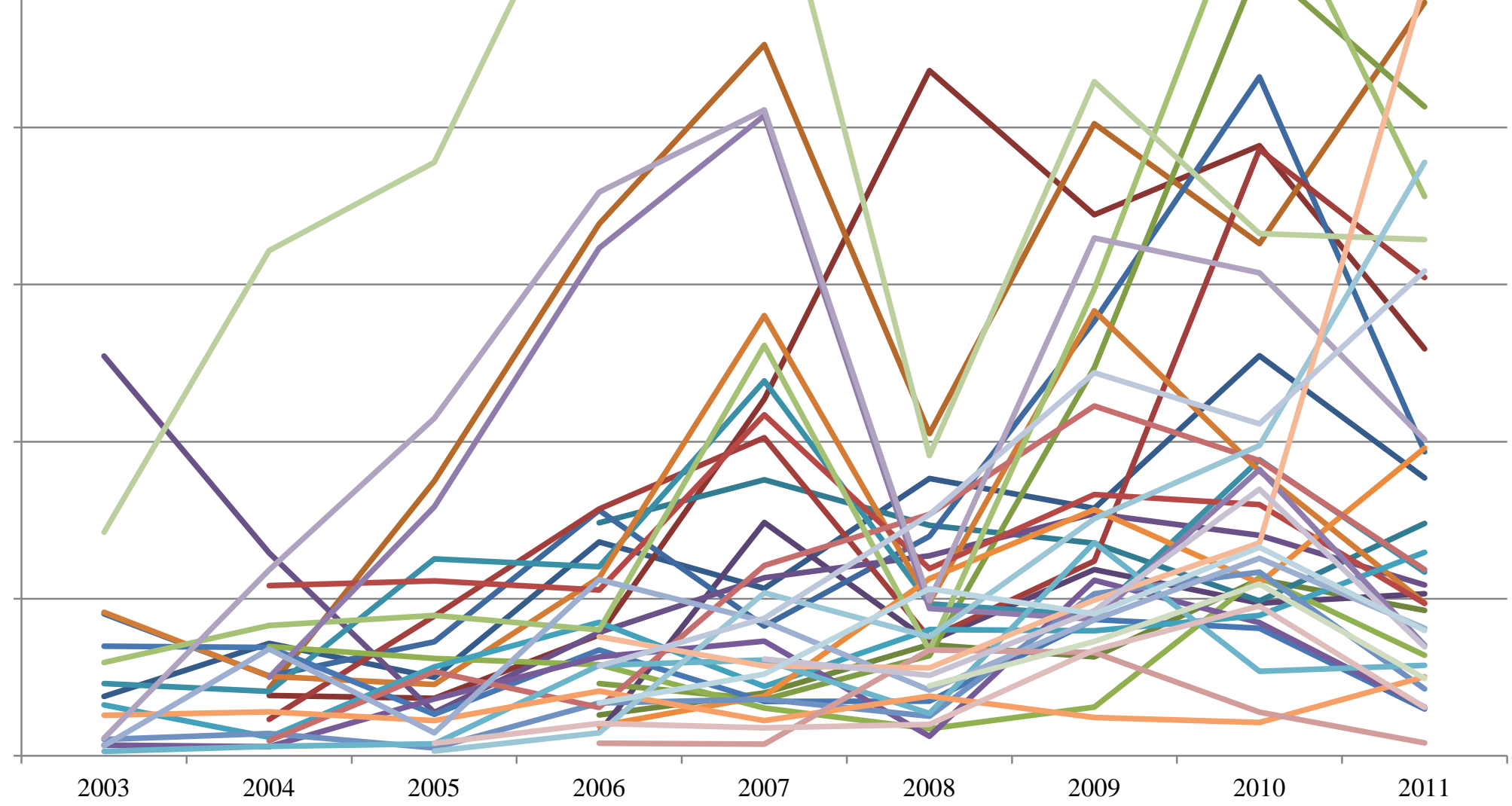

Tianjin

Shijiazhuang

Taiyuan

Huhehaote

Shenyang

-Dalian

Changchun

Haerbin

- Shanghai

- Nanjing

Hangzhou

Ningbo

Hefei

Fuzhou

Xiamen

-Nanchang

Jinan

Qingdao

Zhengzhou

Wuhan

Changsha

Guangzhou

Shenzhen

Nanning

Haikou

Chongqing

Chengdu

Guiyang

Kunming

Xian

Lanzhou

Xining

Yinchuan

Wulumuqi 
Figure 6: Comparison of Real Newly-Built Housing Price Indexes (2006 Q1 = 100)

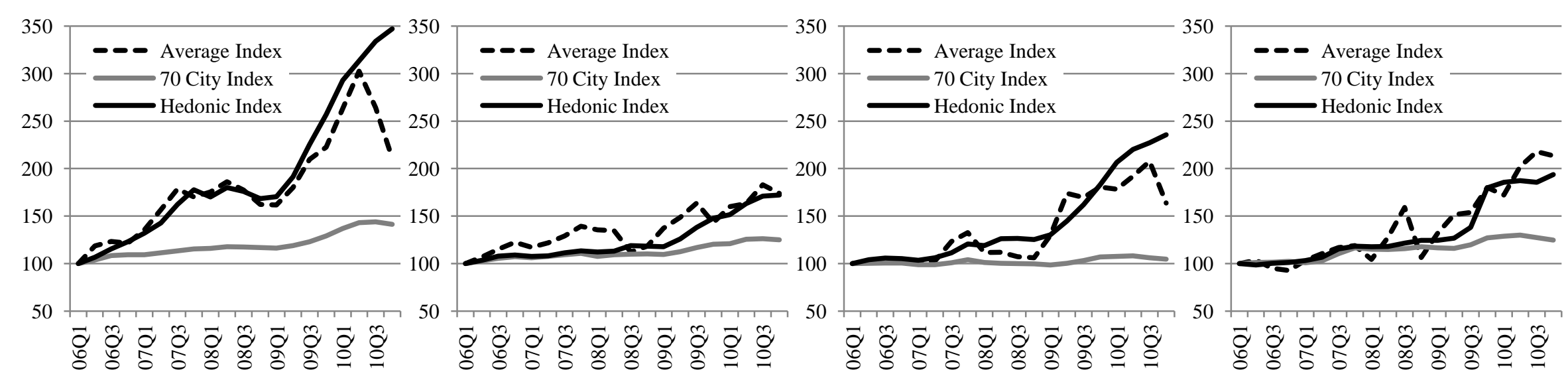

(A) Beijing

(B) Tianjin

(C) Shanghai

(D) Hangzhou

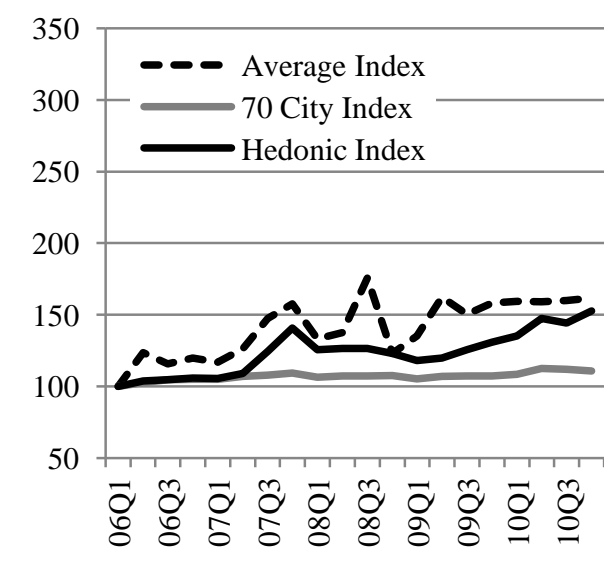

(E) Wuhan

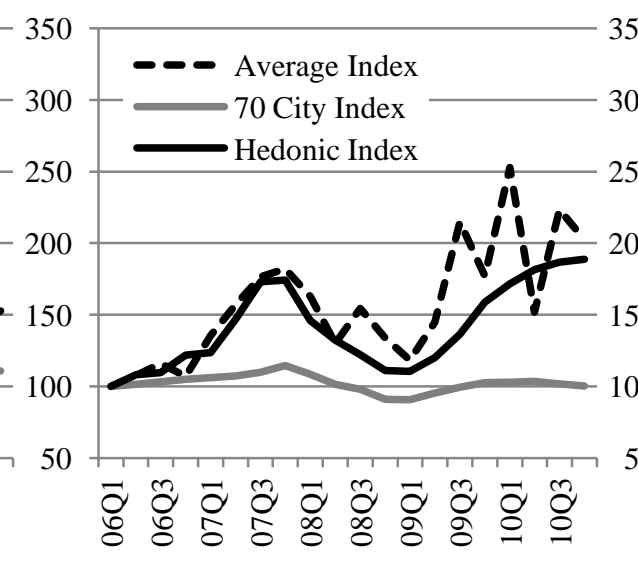

(F) Shenzhen

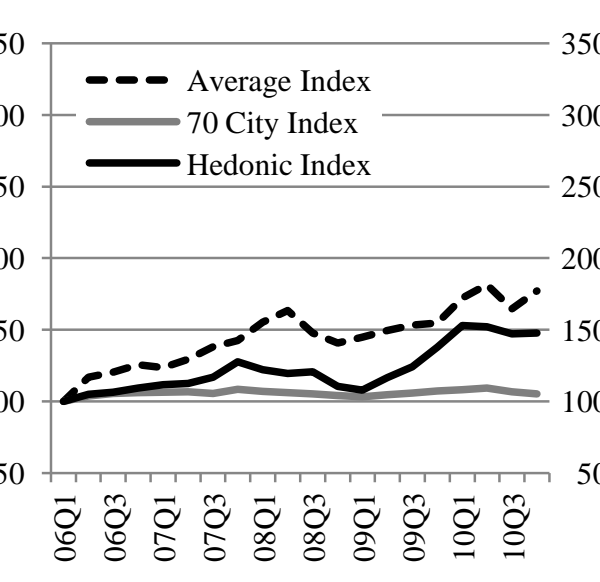

(G) Chengdu

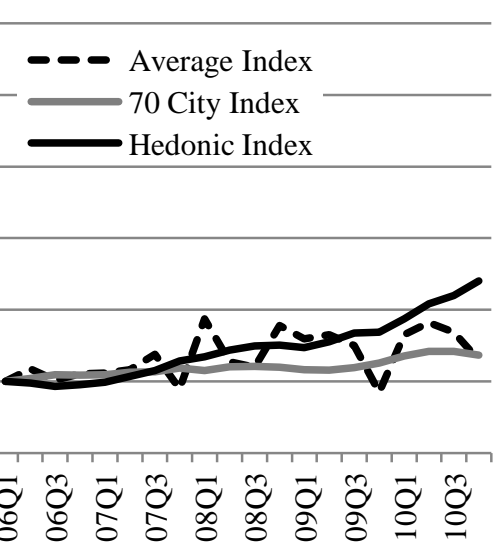

(H) Xian

Source: NBSC and authors' calculations; see the text for details. 
Table 1 Sample Volume of the Land Transaction Dataset

\begin{tabular}{cccc}
\hline & $\begin{array}{c}\text { Number of } \\
\text { Cities Covered }\end{array}$ & $\begin{array}{c}\text { Number of Land } \\
\text { Parcels Sold }\end{array}$ & $\begin{array}{c}\text { Total Floor Area of Land Parcels } \\
\text { Sold (million sq.m.) }\end{array}$ \\
\hline 2003 & 15 & 378 & 44.40 \\
2004 & 22 & 681 & 70.62 \\
2005 & 24 & 773 & 93.49 \\
2006 & 33 & 1133 & 182.68 \\
2007 & 34 & 1413 & 246.47 \\
2008 & 35 & 963 & 169.83 \\
2009 & 35 & 1564 & 281.33 \\
2010 & 35 & 1759 & 336.37 \\
2011 & 35 & 1749 & 288.15 \\
\hline Aggregated & - & 10413 & 1713.34 \\
\hline
\end{tabular}


Table 2: Compounded Real Annual Appreciation Rates in Constant Quality Land Values, 35 Major Chinese Markets (2009 Yuan)

\begin{tabular}{|c|c|c|c|c|c|c|c|c|c|c|c|}
\hline \multicolumn{2}{|c|}{$\begin{array}{c}15 \text { Markets, } 2003-2011 \\
\text { (8 years) }\end{array}$} & \multicolumn{2}{|c|}{$\begin{array}{c}\text { Markets, 2004-2011 } \\
\text { (7 years) }\end{array}$} & \multicolumn{2}{|c|}{$\begin{array}{l}2 \text { Markets, 2005-2011 } \\
\text { (6 years) }\end{array}$} & \multicolumn{2}{|c|}{$\begin{array}{c}9 \text { Markets, 2006-2011 } \\
\text { (5 years) }\end{array}$} & \multicolumn{2}{|c|}{$\begin{array}{c}1 \text { Market, 2007-2011 } \\
\text { (4 years) }\end{array}$} & \multicolumn{2}{|c|}{$\begin{array}{c}1 \text { Market, 2008-2011 } \\
\text { (3 years) }\end{array}$} \\
\hline Chongqing & $27.0 \%$ & Hefei & $30.1 \%$ & Lanzhou & $20.7 \%$ & Huhehaote & $19.7 \%$ & Yinchuan & $8.9 \%$ & Xining & $49.9 \%$ \\
\hline Shanghai & $23.7 \%$ & Changsha & $20.3 \%$ & Guiyang & $12.4 \%$ & Haikou & $17.8 \%$ & & & & \\
\hline Hangzhou & $21.8 \%$ & Tianjin & $20.2 \%$ & & & Taiyuan & $12.2 \%$ & & & & \\
\hline Nanjing & $20.5 \%$ & Fuzhou & $17.7 \%$ & & & Haerbin & $10.8 \%$ & & & & \\
\hline Beijing & $20.2 \%$ & Changchun & $13.9 \%$ & & & Jinan & $7.2 \%$ & & & & \\
\hline Shenzhen & $20.1 \%$ & Shenyang & $13.7 \%$ & & & Xian & $6.9 \%$ & & & & \\
\hline Xiamen & $18.7 \%$ & Zhengzhou & $10.3 \%$ & & & Shijiazhuang & $5.1 \%$ & & & & \\
\hline Ningbo & $18.5 \%$ & & & & & Kunming & $2.0 \%$ & & & & \\
\hline Chengdu & $16.7 \%$ & & & & & Wulumuqi & $-2.9 \%$ & & & & \\
\hline Dalian & $15.8 \%$ & & & & & & & & & & \\
\hline Guangzhou & $14.7 \%$ & & & & & & & & & & \\
\hline Wuhan & $13.3 \%$ & & & & & & & & & & \\
\hline Nanning & $12.3 \%$ & & & & & & & & & & \\
\hline Nanchang & $7.8 \%$ & & & & & & & & & & \\
\hline Qingdao & $5.9 \%$ & & & & & & & & & & \\
\hline
\end{tabular}


Table 3: Annual Real Land Price Appreciation, Summary Statistics, 35 Major Chinese Markets

\begin{tabular}{|c|c|c|c|c|c|c|c|c|}
\hline & $2003-2004$ & $2004-2005$ & $2005-2006$ & $2006-2007$ & $2007-2008$ & $2008-2009$ & $2009-2010$ & $2010-2011$ \\
\hline Mean & $32.1 \%$ & $12.2 \%$ & $23.5 \%$ & $46.4 \%$ & $-5.3 \%$ & $28.5 \%$ & $31.4 \%$ & $2.57 \%$ \\
\hline Standard Deviation & $21.7 \%$ & $23.1 \%$ & $40.5 \%$ & $42.1 \%$ & $24.0 \%$ & $30.7 \%$ & $29.4 \%$ & $30.22 \%$ \\
\hline Max & $64.1 \%$ & $47.2 \%$ & $128.8 \%$ & $131.2 \%$ & $38.6 \%$ & $93.1 \%$ & $83.6 \%$ & $108.58 \%$ \\
\hline Min & $4.4 \%$ & $-28.0 \%$ & $-36.1 \%$ & $-29.2 \%$ & $-59.9 \%$ & $-20.2 \%$ & $-31.6 \%$ & $-44.2 \%$ \\
\hline Number of Cities & 15 & 22 & 24 & 33 & 34 & 35 & 35 & 35 \\
\hline Number with Positive Appreciation & 15 & 15 & 17 & 28 & 18 & 27 & 29 & 16 \\
\hline Number with Negative Appreciation & 0 & 7 & 7 & 5 & 16 & 8 & 6 & 19 \\
\hline
\end{tabular}


Table 4: Average Annual Growth Rates and Standard Deviations, Land Prices, House Prices, Construction Costs and Wages

\begin{tabular}{ccccccccc}
\hline A. Mean of Annual Real Growth Rate & \multicolumn{1}{c}{. } \\
\hline & 2004 & 2005 & 2006 & 2007 & 2008 & 2009 & 2010 & 2011 \\
\cline { 2 - 9 } House Price & $4.14 \%$ & $5.56 \%$ & $6.72 \%$ & $13.60 \%$ & $8.18 \%$ & $9.17 \%$ & $23.31 \%$ & $8.47 \%$ \\
Land Price & $32.07 \%$ & $12.22 \%$ & $23.51 \%$ & $46.39 \%$ & $-5.34 \%$ & $28.46 \%$ & $31.36 \%$ & $2.57 \%$ \\
Construction Cost & $6.26 \%$ & $0.12 \%$ & $0.22 \%$ & $1.26 \%$ & $6.77 \%$ & $-1.87 \%$ & $1.76 \%$ & - \\
Construction Industry Wage & $8.24 \%$ & $12.38 \%$ & $14.19 \%$ & $10.73 \%$ & $8.56 \%$ & $14.62 \%$ & $10.26 \%$ & - \\
Number of Cities Included & 15 & 22 & 25 & 33 & 34 & 35 & 35 & 35 \\
\hline B. Standard Deviation of Annual Real Growth Rate & & & & & & 2011 \\
\hline & 2004 & 2005 & 2006 & 2007 & 2008 & 2009 & 2010 & $2.82 \%$ \\
House Price & $4.91 \%$ & $3.64 \%$ & $6.13 \%$ & $12.41 \%$ & $8.31 \%$ & $6.39 \%$ & $11.60 \%$ & $7.82 \%$ \\
Land Price & $21.68 \%$ & $23.06 \%$ & $40.52 \%$ & $42.11 \%$ & $23.98 \%$ & $30.72 \%$ & $29.44 \%$ & $30.22 \%$ \\
Construction Cost & $2.23 \%$ & $1.68 \%$ & $1.39 \%$ & $1.38 \%$ & $2.49 \%$ & $1.31 \%$ & $1.29 \%$ & - \\
Construction Industry Wage & $5.78 \%$ & $4.29 \%$ & $4.61 \%$ & $5.07 \%$ & $4.33 \%$ & $9.01 \%$ & $4.89 \%$ & - \\
Number of Cities Included & 15 & 22 & 25 & 33 & 34 & 35 & 35 & 35 \\
\hline
\end{tabular}


Table 5: Can Year and City Fixed Effects Explain Local Land Price Growth?

(Dependent Variable: Log Change in Real Annual Land Price Index)

\begin{tabular}{|c|c|c|c|}
\hline Independent Variables & $(1)$ & $(2)$ & (3) \\
\hline Year Fixed Effects & Yes & No & Yes \\
\hline City Fixed Effects & No & Yes & Yes \\
\hline $\mathrm{R}^{2}$ & 0.24 & 0.05 & 0.28 \\
\hline Adjusted $\mathrm{R}^{2}$ & 0.21 & -0.11 & 0.13 \\
\hline F Stat. for the Joint Test of All Year Fixed Effects Equaling 0 & $9.89 * * *$ & - & $8.89 * * *$ \\
\hline F Stat. for the Joint Test of All City Fixed Effects Equaling 0 & - & 0.30 & 0.37 \\
\hline Number of Observations & 233 & 233 & 233 \\
\hline
\end{tabular}

Note: $*<0.1, * * p<0.05, * * * p<0.01$ 
Table 6: Can Time-Varying Local Traits Explain Local Land Price Growth? (2003-2010)

(Dependent Variable: Log Change in Annual Land Price Index)

\begin{tabular}{|c|c|c|}
\hline Independent Variables & $(1)$ & $(2)$ \\
\hline $\begin{array}{l}\text { Expected Employment Growth } \\
\left(\text { epgrowth }_{i, t}\right)\end{array}$ & $\begin{array}{c}0.0825 \\
(0.0530)\end{array}$ & $\begin{array}{l}0.1722 * * \\
(0.0696)\end{array}$ \\
\hline expgrowth $_{i, t} * 2009 / 10$ & - & $\begin{array}{l}-0.2120 * \\
(0.1089)\end{array}$ \\
\hline $\begin{array}{l}\text { Previous Supply-Demand Balance in Housing } \\
\left(\text { hsdratio }_{i, t-1}\right)\end{array}$ & $\begin{array}{l}-0.1245 * * \\
(0.0603)\end{array}$ & $\begin{array}{l}-0.1570^{*} \\
(0.0852)\end{array}$ \\
\hline hsdratio $_{i, t-1} * 2009 / 10$ & - & $\begin{array}{c}0.0231 \\
(0.1222)\end{array}$ \\
\hline $\begin{array}{l}\text { Previous 3-Year Average Loan Volumes to Developers } \\
\left(\text { developloan3yr } r_{i, t}\right)\end{array}$ & $\begin{array}{r}0.0019 * \\
(0.0011)\end{array}$ & $\begin{array}{c}0.0013 \\
(0.0017)\end{array}$ \\
\hline developloan3yr $r_{i, t} * 2009 / 10$ & - & $\begin{array}{c}0.0011 \\
(0.0023)\end{array}$ \\
\hline Year Fixed Effects & Yes & Yes \\
\hline City Fixed Effects & No & No \\
\hline $\mathrm{R}^{2}$ & 0.27 & 0.29 \\
\hline Number of Observations & 183 & 183 \\
\hline
\end{tabular}

Note: (1) Standard errors in parentheses
(2) $* p<0.1, * * p<0.05, * * * p<0.01$
(3) 16 observations are dropped due to the missing value in $h s d r a t i o_{i, t-1}$. 
Table 7: Mean Reversion in Annual Land Price Growth

(Dependent Variable: Log Change in Annual Real Land Price Index)

\begin{tabular}{lllll}
\hline Independent Variables & $(1)$ & $(2)$ & $(3)$ & $(4)$ \\
\hline $\mathrm{d} \log \left(L P_{i, t-1}\right)$ & -0.3527 & -0.4427 & -0.4243 & -0.5961 \\
& $(0.0764)^{* * *}$ & $(0.0891)^{* * *}$ & $(0.0749)^{* * *}$ & $(0.0864)^{* * *}$ \\
$\mathrm{~d} \log \left(L P_{i, t-2}\right)$ & - & -0.1905 & -0.3806 & $(0.0868)^{* * *}$ \\
YEAR2006 & - & $(0.0888)^{* *}$ & - & - \\
& -0.0156 & - & - & - \\
$Y E A R 2007$ & $(0.0909)$ & - & - & - \\
& 0.2479 & 0.3149 & - & - \\
$Y E A R 2008$ & $(0.0891)^{* * *}$ & $(0.0875)^{* * *}$ & - & - \\
YEAR2009 & -0.1850 & -0.1175 & - & - \\
YEAR2010 & $(0.0857)^{* *}$ & $(0.0885)$ & - & - \\
YEAR2011 & -0.0273 & 0.0302 & - & - \\
Constant & $(0.0887)$ & $(0.0840)$ & - & - \\
City Fixed Effects & 0.1151 & 0.1459 & - & - \\
R & $(0.0849)$ & $(0.0865)^{*}$ & - & - \\
Number of Observations & -0.1354 & -0.0567 & - & - \\
\hline
\end{tabular}

Note: (1) Standard errors in parentheses

(2) $* p<0.1, * * p<0.05, * * * p<0.01$ 
Table 8: Augmented Mean Reversion Estimates

(Dependent Variable: Log Change in Real Annual Land Price Index)

\begin{tabular}{|c|c|c|c|c|}
\hline Independent Variables & $(1)$ & $(2)$ & (3) & (4) \\
\hline $\operatorname{dlog}\left(L P_{i, t-1}\right) *\left(\operatorname{dlog}\left(L P_{i, t-1}\right) \geq 0\right)$ & $\begin{array}{l}-0.4323 \\
(0.1173) * * *\end{array}$ & $\begin{array}{l}-1.1490 \\
(0.5071)^{* *}\end{array}$ & $\begin{array}{l}-0.5528 \\
(0.1203)^{* * *}\end{array}$ & $\begin{array}{l}-1.6853 \\
(0.5165) * * *\end{array}$ \\
\hline $\begin{array}{l}\operatorname{dlog}\left(L P_{i, t-1}\right) *\left(\operatorname{dlog}\left(L P_{i, t-1}\right) \geq 0\right) * \\
\text { deficit }_{i, t-1}\end{array}$ & - & $\begin{array}{c}0.4626 \\
(0.3674)\end{array}$ & - & $\begin{array}{l}0.8139 \\
(0.3860)^{* *}\end{array}$ \\
\hline $\mathrm{d} \log \left(L P_{i, t-1}\right) *\left(\mathrm{~d} \log \left(L P_{i, t-1}\right)<0\right)$ & $\begin{array}{l}-0.2039 \\
(0.1831)\end{array}$ & $\begin{array}{c}0.3254 \\
(0.8092)\end{array}$ & $\begin{array}{l}-0.1770 \\
(0.1963)\end{array}$ & $\begin{array}{c}0.7549 \\
(0.8846)\end{array}$ \\
\hline $\begin{array}{l}\operatorname{dlog}\left(L P_{i, t-1}\right) *\left(\operatorname{dlog}\left(L P_{i, t-1}\right)<0\right) * \\
\text { deficit }_{i, t-1}\end{array}$ & - & $\begin{array}{l}-0.3903 \\
(0.5952)\end{array}$ & - & $\begin{array}{l}-0.6748 \\
(0.6557)\end{array}$ \\
\hline Constant & $\begin{array}{l}0.2290 \\
(0.0759) * * *\end{array}$ & $\begin{array}{l}0.2177 \\
(0.0777)^{* * *}\end{array}$ & $\begin{array}{l}0.2542 \\
(0.0391)^{* * *}\end{array}$ & $\begin{array}{l}0.2888 \\
(0.0424) * * *\end{array}$ \\
\hline $\begin{array}{l}\text { Year Fixed Effects } \\
\text { City Fixed Effects }\end{array}$ & $\begin{array}{l}\text { Yes } \\
\text { Yes }\end{array}$ & $\begin{array}{l}\text { Yes } \\
\text { Yes }\end{array}$ & $\begin{array}{l}\text { Yes } \\
\text { Yes }\end{array}$ & $\begin{array}{l}\text { Yes } \\
\text { Yes }\end{array}$ \\
\hline $\begin{array}{l}\mathrm{R}^{2} \\
\text { Number of Observations }\end{array}$ & $\begin{array}{r}0.34 \\
198\end{array}$ & $\begin{array}{r}0.29 \\
163\end{array}$ & $\begin{array}{r}0.13 \\
198\end{array}$ & $\begin{array}{r}0.09 \\
163\end{array}$ \\
\hline
\end{tabular}

Note: (1) Standard errors in parentheses

(2) $* p<0.1, * * p<0.05, * * * p<0.01$ 
Table 9: Summary Statistics on Floor Area Sold, 2003-2010, 35 Chinese Markets (millions of square meters)

\begin{tabular}{lcccccc}
\hline & Mean & $\begin{array}{c}\text { Standard } \\
\text { Deviation }\end{array}$ & 25 Percentile & Median & 75 Percentile & $\begin{array}{c}\text { Number of } \\
\text { Cities Included }\end{array}$ \\
\hline 2003 & 2.86 & 3.13 & 0.53 & 1.89 & 4.52 & 15 \\
2004 & 3.25 & 3.43 & 1.16 & 2.52 & 3.58 & 22 \\
2005 & 3.98 & 4.31 & 1.32 & 2.59 & 5.55 & 24 \\
2006 & 5.62 & 6.25 & 1.68 & 3.79 & 6.02 & 33 \\
2007 & 7.46 & 7.17 & 2.11 & 4.33 & 11.35 & 34 \\
2008 & 5.34 & 4.29 & 2.52 & 4.41 & 7.48 & 35 \\
2009 & 8.04 & 5.72 & 4.55 & 6.20 & 12.36 & 35 \\
2010 & 10.13 & 6.94 & 5.21 & 7.36 & 13.45 & 35 \\
2011 & 9.26 & 7.84 & 3.20 & 6.33 & 12.96 & 35 \\
\hline
\end{tabular}


Table 10: Can Year and City Fixed Effects Explain Local Land Supply Volume? Dependent Variable: Log (Annual Land Supply Volume) (in million sq.m. of floor area)

\begin{tabular}{|c|c|c|c|}
\hline & $(1)$ & $(2)$ & $(3)$ \\
\hline Year Fixed Effects & Yes & No & Yes \\
\hline City Fixed Effects & No & Yes & Yes \\
\hline $\mathrm{R}^{2}$ & 0.22 & 0.42 & 0.68 \\
\hline Adjusted $\mathrm{R}^{2}$ & 0.20 & 0.34 & 0.60 \\
\hline F Stat. for the Joint Test of All Year Fixed Effects Equaling 0 & $8.34 * * *$ & - & $18.18 * * *$ \\
\hline F Stat. for the Joint Test of All City Fixed Effects Equaling 0 & - & $5.03 * * *$ & $8.87 * * *$ \\
\hline Number of Observations & 268 & 268 & 268 \\
\hline
\end{tabular}

Note: ${ }^{*} p<0.1, * * p<0.05, * * * p<0.01$ 
Table 11: Can Politics Factors Explain Local Land Supply Volume? (2003-2010)

(Dependent Variable: Log of Annual Land Supply Volume (in million sq.m. of floor area))

\begin{tabular}{|c|c|c|c|c|}
\hline Independent Variables & (1) & (2) & (3) & (4) \\
\hline $\begin{array}{l}\text { Degree of Budgetary Deficit in the Previous Year } \\
\left(\text { deficit }_{i, t-1}\right)\end{array}$ & $\begin{array}{l}0.9488 * * \\
(0.4253)\end{array}$ & $\begin{array}{l}0.7862 * \\
(0.4573)\end{array}$ & - & - \\
\hline deficit $_{i, t-1} * 2009 / 10$ & - & $\begin{array}{c}0.3012 \\
(0.3084)\end{array}$ & - & - \\
\hline $\begin{array}{l}\text { Degree of Budgetary Deficit in the Current Year } \\
\left(\text { deficit }_{i, t}\right)\end{array}$ & - & - & $\begin{array}{l}1.1884 * * * \\
(0.4407)\end{array}$ & $\begin{array}{l}1.0838 * * \\
(0.4840)\end{array}$ \\
\hline deficit $_{i, t} * 2009 / 10$ & - & - & - & $\begin{array}{c}0.1372 \\
(0.2931)\end{array}$ \\
\hline $\begin{array}{l}\text { Length of CCP Top Officer in Current Position } \\
\left(\text { length }_{i, t}\right)\end{array}$ & $\begin{array}{l}-0.0558 * \\
(0.0285)\end{array}$ & $\begin{array}{l}-0.0713 * * \\
(0.0344)\end{array}$ & $\begin{array}{l}-0.0569 * * \\
(0.0283)\end{array}$ & $\begin{array}{l}-0.0674 * \\
(0.0344)\end{array}$ \\
\hline length $_{i, t} * 2009 / 10$ & - & $\begin{array}{c}0.0406 \\
(0.0523)\end{array}$ & - & $\begin{array}{c}0.0273 \\
(0.0522)\end{array}$ \\
\hline $\begin{array}{l}\text { Year Fixed Effects } \\
\text { City Fixed Effects }\end{array}$ & $\begin{array}{l}\text { Yes } \\
\text { Yes }\end{array}$ & $\begin{array}{l}\text { Yes } \\
\text { Yes }\end{array}$ & $\begin{array}{l}\text { Yes } \\
\text { Yes }\end{array}$ & $\begin{array}{l}\text { Yes } \\
\text { Yes }\end{array}$ \\
\hline $\begin{array}{l}\mathrm{R}^{2} \\
\text { Number of observations }\end{array}$ & $\begin{array}{r}0.22 \\
234\end{array}$ & $\begin{array}{r}0.21 \\
234\end{array}$ & $\begin{array}{r}0.19 \\
234\end{array}$ & $\begin{array}{r}0.19 \\
234\end{array}$ \\
\hline
\end{tabular}

Note: (1) Standard errors in parentheses
(2) $* p<0.1, * * * 00.05, * * * p<0.01$ 
Table 12 Average Real Compound Quarterly House Price Growth Rates (2003-2010)

\begin{tabular}{cccc}
\hline City & "Average Index" & "70 Cities Index" & Hedonic Index \\
\hline Beijing & $4.00 \%$ & $1.83 \%$ & $6.77 \%$ \\
Tianjin & $2.95 \%$ & $1.18 \%$ & $2.90 \%$ \\
Shanghai & $2.63 \%$ & $0.25 \%$ & $4.61 \%$ \\
Hangzhou & $4.08 \%$ & $1.17 \%$ & $3.54 \%$ \\
Wuhan & $2.56 \%$ & $0.54 \%$ & $2.25 \%$ \\
Shenzhen & $3.78 \%$ & $0.01 \%$ & $3.40 \%$ \\
Chengdu & $3.06 \%$ & $0.27 \%$ & $2.08 \%$ \\
Xian & $0.73 \%$ & $0.89 \%$ & $2.84 \%$ \\
\hline
\end{tabular}

Source: NBSC and authors' calculations; see the text for details. 
Appendix Table 1 Summary of Land Price Hedonic Models in 35 Major Cities

\begin{tabular}{|c|c|c|c|}
\hline City & Starting Year & Num. of Obs. & Adjusted $\mathrm{R}^{2}$ \\
\hline Beijing & 2003 & 355 & 0.640 \\
\hline Tianjin & 2004 & 369 & 0.459 \\
\hline Shijiazhuang & 2006 & 94 & 0.425 \\
\hline Taiyuan & 2006 & 141 & 0.360 \\
\hline Huhehaote & 2006 & 276 & 0.325 \\
\hline Shenyang & 2004 & 654 & 0.494 \\
\hline Dalian & 2003 & 473 & 0.620 \\
\hline Changchun & 2004 & 373 & 0.350 \\
\hline Haerbin & 2006 & 354 & 0.525 \\
\hline Shanghai & 2003 & 460 & 0.653 \\
\hline Nanjing & 2003 & 367 & 0.592 \\
\hline Hangzhou & 2003 & 565 & 0.663 \\
\hline Ningbo & 2003 & 239 & 0.491 \\
\hline Hefei & 2004 & 336 & 0.561 \\
\hline Fuzhou & 2004 & 153 & 0.723 \\
\hline Xiamen & 2003 & 150 & 0.715 \\
\hline Nanchang & 2003 & 251 & 0.379 \\
\hline Jinan & 2006 & 232 & 0.367 \\
\hline Qingdao & 2003 & 161 & 0.444 \\
\hline Zhengzhou & 2004 & 214 & 0.242 \\
\hline Wuhan & 2003 & 486 & 0.418 \\
\hline Changsha & 2004 & 495 & 0.294 \\
\hline Guangzhou & 2003 & 139 & 0.380 \\
\hline Shenzhen & 2003 & 66 & 0.455 \\
\hline Nanning & 2003 & 218 & 0.237 \\
\hline Haikou & 2006 & 61 & 0.184 \\
\hline Chongqing & 2003 & 906 & 0.584 \\
\hline Chengdu & 2003 & 553 & 0.694 \\
\hline Guiyang & 2005 & 162 & 0.177 \\
\hline Kunming & 2006 & 175 & 0.251 \\
\hline Xian & 2006 & 357 & 0.437 \\
\hline Lanzhou & 2005 & 76 & 0.485 \\
\hline Xining & 2008 & 93 & 0.240 \\
\hline Yinchuan & 2007 & 97 & 0.348 \\
\hline Wulumuqi & 2006 & 317 & 0.171 \\
\hline
\end{tabular}

